Working Paper/Document de travail 2015-2

\title{
International Spillovers of Large-Scale Asset Purchases
}

by Sami Alpanda and Serdar Kabaca 
Bank of Canada Working Paper 2015-2

January 2015

\title{
International Spillovers of Large-Scale Asset Purchases
}

\author{
by \\ Sami Alpanda ${ }^{1}$ and Serdar Kabaca ${ }^{2}$ \\ ${ }^{1}$ Canadian Economic Analysis Department \\ 2International Economic Analysis Department \\ Bank of Canada \\ Ottawa, Ontario, Canada K1A 0G9 \\ alpa@bankofcanada.ca \\ kaba@bankofcanada.ca
}

Bank of Canada working papers are theoretical or empirical works-in-progress on subjects in economics and finance. The views expressed in this paper are those of the authors. No responsibility for them should be attributed to the Bank of Canada. 


\section{Acknowledgements}

We thank Paul Beaudry, Rose Cunningham, Michael Ehrmann, Jean-Sébastien Fontaine, Yuko Imura, Rhys Mendes, Ke Pang, Abeer Reza, Subrata Sarker, and seminar participants at the Bank of Canada, CEA 2014, Midwest Macro (Fall) Meetings 2014, the Bank of Italy, and the 2014 European Winter Meetings of the Econometric Society for suggestions and comments. All remaining errors are our own. 


\begin{abstract}
This paper evaluates the international spillover effects of large-scale asset purchases (LSAPs) using a two-country dynamic stochastic general-equilibrium model with nominal and real rigidities, and portfolio balance effects. Portfolio balance effects arise from imperfect substitution between short- and long-term bond portfolios in each country, as well as between domestic and foreign bonds within these portfolios. We show that LSAPs lower both domestic and foreign long-term yields, and stimulate economic activity in both countries. International spillover effects become larger as the steady-state share of long-term U.S. bond holdings increases in the rest-of-the-world portfolio, as the elasticity of substitution between short- and long-term bonds decreases, or as the elasticity of substitution between domestic and foreign bonds increases. We also find that U.S. asset purchases that generate the same output effect as U.S. conventional monetary policy have larger international spillover effects. This is because portfolio balance effects appear to be stronger under unconventional policy, and foreigners' U.S. bond holdings are heavily weighted toward long-term bonds.
\end{abstract}

JEL classification: E52, F41

Bank classification: International topics; Transmission of monetary policy; Economic models

\title{
Résumé
}

Dans cette étude, les auteurs évaluent les effets de débordement internationaux des achats massifs d'actifs en s'appuyant sur un modèle d'équilibre général dynamique et stochastique à deux pays intégrant des rigidités réelles et nominales et les effets liés aux rééquilibrages des portefeuilles. Ces effets sont attribuables au fait que les portefeuilles d'obligations à court terme et d'obligations à long terme de chaque pays ne constituent pas des substituts parfaits, de même que les obligations nationales et étrangères au sein de ces portefeuilles. Les auteurs montrent que les achats massifs d'actifs font diminuer les rendements des obligations nationales et étrangères à long terme et stimulent l'activité économique dans les deux pays, à savoir les États-Unis et le reste du monde. Les effets de débordement internationaux prennent de l'ampleur lorsque la part des obligations américaines à long terme en régime permanent dans le portefeuille du reste du monde est plus grande, lorsque l'élasticité de substitution entre les obligations à court et long terme diminue ou lorsque l'élasticité de substitution entre les obligations nationales et étrangères augmente. Les auteurs constatent également que si les programmes d'achat d'actifs de la Réserve fédérale peuvent générer des répercussions similaires sur la production que sa politique monétaire traditionnelle, leurs effets de débordement internationaux sont plus importants. Cette constatation s'explique par deux facteurs : les effets liés aux rééquilibrages des portefeuilles induits par la politique non traditionnelle semblent plus marqués, et les détenteurs étrangers d'obligations américaines affichent une forte préférence pour les obligations à long terme.

Classification JEL : E52, F41

Classification de la Banque : Questions internationales; Transmission de la politique monétaire; Modèles économiques 


\section{Non-Technical Summary}

\section{Motivation and Question}

In the aftermath of the crisis, the Federal Reserve lowered the federal funds rate to its effective lower bound, and announced unprecedented unconventional measures such as large-scale asset purchases (LSAPs) to provide further stimulus to the U.S. economy. In this paper, we analyze the international spillover effects of these policies on the rest-of-the-world (ROW) economic activity, inflation, short- and long-term interest rates, exchange rates, and trade balance. We then compare these spillover effects with those that would result from conventional monetary policy in the United Sates.

\section{Methodology}

We propose a two-country dynamic general-equilibrium model with nominal and real rigidities, and portfolio balance effects. Portfolio balance effects arise from imperfect substitution between short- and long-term bond portfolios in each country, as well as between domestic and foreign bonds within these portfolios. Imperfect substitution among bonds makes term premia, exchange rates and aggregate demand depend on the relative quantities of bond holdings. The model is calibrated to capture the key features of the U.S. economy, and the bond holdings of U.S. and ROW residents. Using the model, we analyze the domestic and the international spillover effects of the second round of LSAPs in the United States (i.e., QE2). We also perform sensitivity analyses on the steady-state share of ROW holdings of U.S. long-term bonds and the substitutability among different bonds in agents' portfolios.

\section{Key Contributions and Results}

We show that LSAPs lower both domestic and foreign long-term bond yields, and stimulate economic activity in the United States and ROW, mainly through financial channels. Following LSAPs, the U.S. term premium and long-term interest rates fall, making ROW long-term bonds more attractive relative to their U.S. counterparts. The resulting portfolio reallocation also drives down the term premium in the ROW, and leads to an appreciation in their currency, which pushes the ROW inflation and policy rates downward. The decline in ROW long-term yields is mostly driven by the decline in the term premium rather than expected policy rates, however. (Thus, our quantitative results would be similar if the ROW is also assumed to be facing the zero lower bound so that the ROW policy rate cannot decline as well.) Lower rates stimulate domestic demand in the ROW, while their real exports increase due to higher incomes in the United States. Nevertheless, the ROW's imports increase more than their exports due to the appreciation in the ROW currency, leading to an overall deterioration in their trade balance.

International spillover effects become larger as the ROW holds a larger share of long-term U.S. bonds in their portfolios prior to the announcement of LSAPs in the United States. Spillover effects also increase as the substitutability between short- and long-term portfolios decreases, or as the substitutability between long-term foreign and home bonds increases. We also find that U.S. asset purchases that generate the same output effect as U.S. conventional monetary policy have larger international spillover effects. This is because portfolio balance effects appear to be stronger under unconventional policy, and foreigners' U.S. bond holdings are heavily weighted toward long-term bonds.

\section{Future Work and Comments}

In future research, we plan to use the model to analyze the effects of tapering of asset purchases and normalization of monetary policy in advanced economies. In addition, we plan to differentiate emerging-market economies in the ROW block by introducing unconventional responses of EMEs to monetary policies in advanced economies, such as foreign exchange interventions and capital controls. 


\section{Introduction}

Following the financial turbulence in the fall of 2008, the Federal Reserve cut short-term policy rates to near-zero, and announced unprecedented unconventional policy measures, such as large-scale asset purchases (LSAPs; also known as quantitative easing or QE), at the zero lower bound. Several studies have found significant effects of these asset purchases in terms of lowering U.S. long-term yields and strengthening economic activity (see, among others, Baumeister and Benati, 2013; D'Amico et al., 2012; Gagnon et al., 2011; and Krishnamurthy and Vissing-Jorgensen, 2011) 1 The domestic effects of these policies may also have increased the attractiveness of foreign assets, and led to portfolio rebalancing by international investors. Figure 1 shows the exchange rate and long-term yield movements during this period in countries where the policy rates were not significantly binding, and QE-type unconventional measures were not expected to be undertaken. The figure suggests that the currencies of these countries tended to appreciate during and after the announcement of LSAPs in the United States. Long-term yields were also in declining trend during this period; on average, long-term rates had fallen by more than 1 percentage point (pp) by mid-2013 when the Fed started talking about "tapering" the quantity of its asset purchases, in preparation for an eventual return to policy normalization 2 In their analyses, Bauer and Neely (2014) and Neely (2013) find substantial effects of LSAPs on international financial markets through a decline in foreign yields and depreciation of the U.S. dollar. Chen et al. (2012b), Fratzscher et al. (2013), and Lim et al. (2014) also document significant spillover effects of $\mathrm{QE}$ on the financial markets of emerging economies.

In this paper, we propose a two-country, open-economy model in which agents in the rest-of-the-world (ROW) economy hold both short- and long-term U.S. government bonds as well as their domestic bonds, but cannot perfectly substitute among these bonds. We show that the model can generate the type of international spillovers mentioned above after a QE announcement in the United States through the portfolio balance channel. We capture these portfolio balance effects by introducing a portfolio preference in households' utility function with a constant elasticity of substitution (CES) structure to aggregate individual financial assets. The imperfect substitution between short- and long-term bonds, as well as between domestic and foreign bonds, could represent attitudes toward differential risk on these assets, costs of portfolio adjustment, or the institutional use of these bonds for liquidity purposes with varying degrees ${ }^{3}$ When short- and long-

\footnotetext{
${ }^{1}$ Hamilton and $\mathrm{Wu}(2012)$ and Doh (2010) find more limited effects of LSAPs on U.S. long-term yields. The estimates in the literature range between a 3 and 15 basis points (bps) decline in long-term interest rates per $\$ 100$ billion asset purchase conducted by the Federal Reserve (Chen et al., 2012a). For LSAP2, in particular, Bernanke (2012) reports a range of a 2.5 to 7.5 bps decline in long-term yields per $\$ 100$ billion asset purchase. Our baseline findings for the decline in the term premium and long-term yields as a result of LSAP2 fall within this range (about 4-5 bps). In section 5, we also conduct a sensitivity analysis to determine under which conditions the effects of LSAPs can be smaller or larger.

${ }^{2}$ Long-term yields increased in the beginning of LSAP2, mainly because central banks in many countries hiked interest rates in expectation of higher inflation. However, this tightening cycle was short (about a year), since these expectations did not materialize. Contagion effects from the euro crisis could have also put upward pressure on long-term yields during this period.

${ }^{3}$ Financial institutions, for example, use short-term money market instruments as collateral in the interbank market. Thus, they may be less willing to alter their portfolio balances when there is a change in the relative prices of short-term to long-term assets. In addition, regardless of maturity, domestic and foreign assets tend to be less substitutable with each other. Hau and Rey (2004), for instance, find evidence in support of the portfolio balance channel affecting exchange rates using a vector
} 
term bonds are perfectly substitutable, exogenous changes in the relative supply of one type of asset would have no effect on the relative price of these bonds (see Curdia and Woodford, 2011). In our set-up, short- and long-term bonds are not perfect substitutes; thus, long-term rates fall in response to a drop in their relative supply even when short-term rates remain constant 4 Lower long-term rates then stimulate the domestic economy, and generate appreciation pressures on the currency of the ROW economy. This in turn leads current and expected policy rates to fall in the ROW, lowering foreign long-term yields. Long-term rates in the ROW fall not only through the expectations hypothesis, but also due to the fall in the term-premium component, which in turn is caused by a relative increase in the demand for ROW long-term assets. Finally, lower short- and long-term interest rates stimulate economic activity in the ROW.

Our results can be summarized as follows: (i) QE is effective to stimulate both U.S. and ROW activity, (ii) QE spillovers are larger than standard monetary policy spillovers when both policies are scaled to have the same output effects in the United States, (iii) spillovers are larger if the steady-state share of long-term U.S. bond holdings is higher in the ROW portfolio (conversely, QE spillovers are smaller, and get close to those from conventional policy, if the steady-state share of long-term U.S. bond holdings is smaller in the ROW portfolio), (iv) spillovers increase as the elasticity of substitution between short- and long-term bonds gets smaller, and (v) spillovers increase as the elasticity of substitution between long-term U.S. and ROW bonds gets larger. An advantage of introducing maturity structure in a two-country open-economy model is that it allows us to analyze the effects of the maturity composition of U.S. government bonds in foreigners' portfolios. Figure 2 shows U.S. residents' and ROW holdings of U.S. government bonds as a ratio of their GDP. The picture highlights a clear difference in the maturity composition in the U.S. and ROW portfolios. In particular, U.S. residents hold twice as many short-term U.S. government bonds as long-term ones. On the other hand, the ratio switches in favor of long-term U.S. government bonds in the ROW. This difference in the maturity composition is crucial to generate a stronger spillover from LSAPs relative to conventional policy in our model.

Our paper is related to the literature on the portfolio balance channel that dates back at least to Tobin (1969). Andres et al. (2004) incorporate Tobin's ideas into a dynamic stochastic general-equilibrium (DSGE) model generating imperfect substitution between assets through transaction costs on long-term bonds. Chen et al. (2012a) use this kind of set-up to study the effects of QE in a closed-economy context. Dorich et al. (2012) also consider a similar set-up and analyze the effects of QE within a small open economy featuring the exchange rate channel. We extend these analyses to a two-country context to study the cross-country spillover effects of QE policies. Note that the models in the literature typically feature "restricted agents"

autoregressive framework. Benes et al. (2013a), Blanchard et al. (2005) and Kumhof (2010) investigate the portfolio balance channel in theoretical frameworks. These papers focus on current account determination and the effects of sterilized interventions, and do not explore the spillover effects of QE.

${ }^{4}$ This is consistent with empirical evidence presented by Gagnon et al. (2011) and Greenwood and Vayanos (2010, 2014) on the relationship between relative bond supplies and the relative returns on government bonds of different maturities. 
that can only hold long-term bonds to smooth consumption; hence, long-term interest rates have an effect on aggregate demand separate from the effects coming from changes in short-term rates. In our set-up, though, we do not need to introduce restricted agents separately to generate real effects from changes in long-term rates. This is because our representative households get utility from holding financial assets; thus, their marginal decision with respect to holding a short-term bond or spending depends not only on the short-term rate but also on their relative bond holdings. Large increases in the U.S. short-term bond holdings following QE lowers the marginal benefit of holding these bonds, thus making short-term U.S. bonds less attractive relative to consumption even when the domestic short-term rate remains constant:5

The remainder of the paper proceeds as follows. The next section introduces the model. Section 3 discusses the calibration of model parameters. Section 4 reports the results of the baseline QE experiment. Section 5 conducts a sensitivity analysis, and section 6 concludes.

\section{Model}

In this study, we use a two-country large-open-economy DSGE model with real and nominal rigidities, and portfolio balance effects ${ }^{6}$ The latter is achieved through modelling households' preferences on the composition of their financial portfolio with imperfect substitution between short- and long-term assets for both domestic and foreign sovereign debt. Each country in the model is populated by households, capital producers, finalgoods aggregators, domestic producers, and importers, as well as fiscal and monetary policy rules. In what follows, we focus on the agents in the domestic economy, but the foreign economy is analogous in our set-up. When variables from the foreign economy are necessary, we denote them with a $\left(^{*}\right)$ superscript.

\subsection{Households}

The economy is populated by a unit measure of infinitely-lived patient households indexed by $i$, whose intertemporal preferences over consumption, $c_{t}$, financial asset portfolio, $a_{t}$, and labor supply, $n_{t}$, are described by the following expected utility function:

$$
E_{t} \sum_{\tau=t}^{\infty} \beta^{\tau-t}\left[\log \left[c_{\tau}(i)-\zeta c_{\tau-1}\right]+\xi_{a} \log a_{\tau}(i)-\xi_{n} \frac{n_{\tau}(i)^{1+\vartheta}}{1+\vartheta}\right],
$$

\footnotetext{
${ }^{5}$ Harrison (2012) also analyzes the effects of asset purchases by using a preferred short-to-long-term bond ratio in households' preferences, similar to our paper, but in a closed-economy environment. We use a more general CES structure for financial assets, which allows for a more compact way to introduce imperfect substitution among four different bonds (short-term and long-term bonds in domestic asset and foreign asset portfolios), and also lets us evaluate the economic consequences of different elasticities of substitution between these bonds. Note also that it is common in the finance literature to consider financial wealth in the utility function for determining optimal portfolios. For example, Vayanos and Vila (2009) model the term structure of interest rates using a preference specification for specific maturities. In footnote 7 in the next section, we discuss several alternative modelling choices that would yield similar results with our asset preference specification.

${ }^{6}$ We assume that both regions have the same economic size, which is motivated by the fact that the output of countries that faced the zero lower bound at the end of 2010 - i.e., the United States, United Kingdom and Japan - constitute more than $46 \%$ of world GDP over the sample period 1960-2010. The ratio is slightly lower if we consider a more recent sample period 2000-2010.
} 
where $t$ indexes time, $\beta<1$ is the time-discount parameter, $\zeta$ is the external habit parameter for consumption, $\vartheta$ is the inverse of the Frisch elasticity of labor supply, and $\xi_{a}$ and $\xi_{n}$ are level parameters that determine the relative importance of financial assets and labor in the utility function.

\subsubsection{Preferences on portfolio composition}

We capture imperfect substitution across assets of different currencies and maturities using a nested CES structure for financial assets 7 In particular, the asset portfolio in the utility function, $a_{t}$, is a CES aggregate of subportfolios consisting of short-term bonds, $a_{S, t}$, and long-term bonds, $a_{L, t}$ :

$$
a_{t}(i)=\left[\gamma_{a}^{\frac{1}{\lambda_{a}}} a_{S, t}(i)^{\frac{\lambda_{a}-1}{\lambda_{a}}}+\left(1-\gamma_{a}\right)^{\frac{1}{\lambda_{a}}} a_{L, t}(i)^{\frac{\lambda_{a}-1}{\lambda_{a}}}\right]^{\frac{\lambda_{a}}{\lambda_{a}-1}}
$$

where $\gamma_{a}$ determines the share of short-term assets in the aggregate portfolio, and $\lambda_{a}$ is the elasticity of substitution between short- and long-term assets.

The short-term bond subportfolio is a CES aggregate of short-term domestic government bonds, $B_{H S, t}$, and short-term foreign government bonds, $B_{F S, t}$ :

$$
a_{S, t}(i)=\left[\gamma_{S}^{\frac{1}{\lambda_{S}}}\left(\frac{B_{H S, t}(i)}{P_{t}}\right)^{\frac{\lambda_{S}-1}{\lambda_{S}}}+\left(1-\gamma_{S}\right)^{\frac{1}{\lambda_{S}}}\left(\frac{e_{t} B_{F S, t}(i)}{P_{t}}\right)^{\frac{\lambda_{S}-1}{\lambda_{S}}}\right]^{\frac{\lambda_{S}}{\lambda_{S}-1}},
$$

where $P_{t}$ is the aggregate price level, $e_{t}$ is the nominal exchange rate (in units of domestic currency per unit of foreign currency), $\gamma_{S}$ is the share of domestic bonds in the short-term bond subportfolio, and $\lambda_{S}$ is the elasticity of substitution between domestic and foreign short-term bonds.

Similarly, the long-term bond subportfolio is a CES aggregate of long-term domestic government bonds, $B_{H L, t}$, and long-term foreign government bonds, $B_{F L, t}$ :

$$
a_{L, t}(i)=\left[\gamma_{L}^{\frac{1}{\lambda_{L}}}\left(\frac{q_{L, t} B_{H L, t}(i)}{P_{t}}\right)^{\frac{\lambda_{L}-1}{\lambda_{L}}}+\left(1-\gamma_{L}\right)^{\frac{1}{\lambda_{L}}}\left(\frac{e_{t} q_{L, t}^{*} B_{F L, t}(i)}{P_{t}}\right)^{\frac{\lambda_{L}-1}{\lambda_{L}}}\right]^{\frac{\lambda_{L}}{\lambda_{L}-1}}
$$

where $q_{L, t}$ and $q_{L, t}^{*}$ denote the relative prices of domestic and foreign long-term bonds, respectively, $\gamma_{L}$ is the share of domestic bonds in the long-term bond subportfolio, and $\lambda_{L}$ is the elasticity of substitution between domestic and foreign long-term bonds.

\footnotetext{
${ }^{7}$ Alternatively, we could capture imperfect substitution across the four types of assets by considering portfolio adjustment costs in the budget constraint of households (Chen et al., 2012a). One could also capture this imperfect substitutability in the objective function, or in the flow constraint, of portfolio managers who own the different financial assets, and sell mutual fund shares backed by these assets to households, similar to Harrison (2011). These approaches would yield similar results with our approach in terms of portfolio dynamics and relative asset demand.
} 


\subsubsection{Wage rigidity}

Labor services are heterogeneous across the patient households, and are aggregated into a homogeneous labor service by perfectly-competitive labor intermediaries, who in turn rent these labor services to goods producers. The labor intermediaries use a standard Dixit-Stiglitz aggregator; therefore, the labor demand curve facing each patient household is given by

$$
n_{t}(i)=\left(\frac{W_{t}(i)}{W_{t}}\right)^{-\eta_{n}} n_{t}
$$

where $W_{t}$ and $n_{t}$ are the aggregate nominal wage rate and labor services for patient households, respectively, and $\eta_{n}$ is the elasticity of substitution between the differentiated labor services, implying a steady-state markup of the real wage over the marginal rate of substitution, $\theta_{w}=\eta_{n} /\left(\eta_{n}-1\right)$.

Wage stickiness is introduced via a quadratic cost of wage adjustment in the budget constraint similar to Rotemberg (1982),

$$
\frac{\kappa_{w}}{2}\left(\frac{W_{t}(i) / W_{t-1}(i)}{\pi_{t-1}^{\varsigma_{w}} \pi^{1-\varsigma_{w}}}-1\right)^{2} \frac{W_{t}}{P_{t}} n_{t}
$$

where $\kappa_{w}$ is a scale parameter, $\pi_{t}=P_{t} / P_{t-1}$ is the aggregate inflation factor, and $\varsigma_{w}$ determines indexation of wage adjustments to past inflation.

\subsubsection{Budget constraint}

The households' period budget constraint is given by

$$
\begin{gathered}
c_{t}(i)+q_{t}\left[k_{t}(i)-(1-\delta) k_{t-1}(i)\right]+\frac{B_{H S, t}(i)}{P_{t}}+\frac{e_{t} B_{F S, t}(i)}{P_{t}}+\frac{q_{L, t} B_{H L, t}(i)}{P_{t}}+\frac{e_{t} q_{L, t}^{*} B_{F L, t}(i)}{P_{t}} \\
\leq \frac{W_{t}(i)}{P_{t}} n_{t}(i)+r_{k, t} k_{t-1}(i)+\frac{R_{t-1} B_{H S, t-1}(i)}{P_{t}}+\frac{e_{t} R_{t-1}^{*} B_{F S, t-1}(i)}{P_{t}}+\frac{\left(1+\kappa q_{L, t}\right) B_{H L, t-1}(i)}{P_{t}} \\
\quad+\frac{e_{t}\left(1+\kappa q_{L, t}^{*}\right) B_{F L, t-1}(i)}{P_{t}}+\frac{\Pi_{H, t}}{P_{t}}+\frac{\Pi_{F, t}}{P_{t}}-\frac{T A X_{t}}{P_{t}}-\text { wage adj. cost, }
\end{gathered}
$$

where $k_{t}$ is the capital stock, $q_{t}$ is the relative price of capital, and $r_{k, t}$ is the rental rate of capital. $\Pi_{H, t}$ and $\Pi_{F, t}$ denote the profits of monopolistically-competitive domestic producers and importers, while $T A X_{t}$ is lump-sum taxes paid by households to the government. Short-term domestic and foreign bonds pay predetermined interest rates of $R_{t-1}$ and $R_{t-1}^{*}$, respectively, while long-term bonds are perpetuities that pay a coupon payment of 1 unit in the first period after issuance and have coupon payments decaying at a rate of $\kappa$ for each period after that, as in Woodford (2001). Since these long-term bonds are tradable, we can write them in recursive form in the budget constraint above. The yields on domestic and foreign long-term bonds are defined, respectively, as

$$
R_{L, t}=\frac{1+\kappa q_{L, t}}{q_{L, t}} \text { and } R_{L, t}^{*}=\frac{1+\kappa q_{L, t}^{*}}{q_{L, t}^{*}}
$$




\subsubsection{Short-term and long-term IS curves}

The households' objective is to maximize utility subject to the budget constraint, the labor demand curve of labor intermediaries, and appropriate No-Ponzi conditions. The first-order conditions for consumption and capital are standard, and are given by

$$
\begin{aligned}
& \frac{1}{c_{t}-\zeta c_{t-1}}=\lambda_{t} \\
& q_{t}=E_{t}\left[\left(\beta \frac{\lambda_{t+1}}{\lambda_{t}}\right)\left[(1-\delta) q_{t+1}+r_{k, t+1}\right]\right]
\end{aligned}
$$

where $\lambda_{t}$ is the Lagrange multiplier on the budget constraint. Similarly, the optimality conditions with respect to labor and wages can be combined to derive a New Keynesian wage Phillips curve, which after log-linearization can be written as

$$
\widehat{\pi}_{w, t}-\varsigma_{w} \widehat{\pi}_{t-1}=\beta E_{t}\left[\widehat{\pi}_{w, t+1}-\varsigma_{w} \widehat{\pi}_{t}\right]-\frac{\eta_{n}-1}{\kappa_{w}}\left(\widehat{w}_{t}-\vartheta \widehat{n}_{t}-\frac{1}{1-\zeta}\left(\widehat{c}_{t}-\zeta \widehat{c}_{t-1}\right)\right),
$$

where the nominal wage inflation, $\widehat{\pi}_{w, t}$, and the real wage rate, $\widehat{w}_{t}$, are related as

$$
\widehat{\pi}_{w, t}-\widehat{\pi}_{t}=\widehat{w}_{t}-\widehat{w}_{t-1}
$$

The optimality conditions with respect to domestic short- and long-term bonds are given by

$$
\begin{gathered}
\lambda_{t}=\beta E_{t}\left[\lambda_{t+1} \frac{R_{t}}{\pi_{t+1}}\right]+\frac{\xi_{a}}{a_{t}} \frac{\partial a_{t}}{\partial a_{S, t}} \frac{\partial a_{S, t}}{\partial b_{H S, t}}, \\
q_{L, t} \lambda_{t}=\beta E_{t}\left[\lambda_{t+1} \frac{1+\kappa q_{L, t+1}}{\pi_{t+1}}\right]+\frac{\xi_{a}}{a_{t}} \frac{\partial a_{t}}{\partial a_{L, t}} \frac{\partial a_{L, t}}{\partial b_{H L, t}},
\end{gathered}
$$

where $b_{H S, t}=B_{H S, t} / P_{t}$, and $b_{H L, t}=B_{H L, t} / P_{t}$. The two expressions above can be log-linearized and combined to generate an expression for the yield on long-term bonds as

$$
\widehat{R}_{L, t}=\left(1-\frac{\kappa}{R_{L}}\right) \Omega E_{t} \sum_{s=0}^{\infty}\left(\beta \frac{R}{\pi} \frac{\kappa}{R_{L}} \Omega\right)^{s}\left[\beta \frac{R}{\pi} \widehat{R}_{t+s}+\left(1-\beta \frac{R}{\pi}\right) \widehat{T}_{t+s}\right],
$$

where

$$
\widehat{T}_{t}=\frac{1}{\lambda_{a}}\left(\widehat{a}_{L, t}-\widehat{a}_{S, t}\right)-\frac{1}{\lambda_{L}}\left(\widehat{a}_{L, t}-\widehat{b}_{H L, t}\right)+\frac{1}{\lambda_{S}}\left(\widehat{a}_{S, t}-\widehat{b}_{H S, t}\right)
$$

and

$$
\Omega=\frac{1}{1-\left(1-\beta \frac{R}{\pi}\right)\left(1-\frac{1}{\lambda_{L}}\right)} .
$$

The above expression implies that the yield on long-term bonds, $R_{L, t}$, is a function of expected short-term rates as well as a term premium, which in turn depends on the relative holdings of bonds in agents' portfolios. Note that when the elasticity of substitution across the different assets are set equal to each other (i.e., 
$\left.\lambda_{a}=\lambda_{S}=\lambda_{L}\right)$, the above expression reduces to

$$
\widehat{R}_{L, t}=\left(1-\frac{\kappa}{R_{L}}\right) \Omega E_{t} \sum_{s=0}^{\infty}\left(\beta \frac{R}{\pi} \frac{\kappa}{R_{L}} \Omega\right)^{s}\left[\beta \frac{R}{\pi} \widehat{R}_{t}+\left(1-\beta \frac{R}{\pi}\right) \frac{1}{\lambda_{a}}\left(\widehat{b}_{H L, t}-\widehat{b}_{H S, t}\right)\right]
$$

where the relative quantities of only the domestic short- and long-term bonds affect the domestic term premium, and $\lambda_{a}$ determines the pass-through from changes in relative bond holdings to the long-term yields. When we calibrate the model in the next section, we assume that U.S. households do not hold any ROW bonds; thus, this reduced expression for long-term yields above would apply to the U.S. economy exactly, since $a_{L, t}=b_{H L, t}$ and $a_{S, t}=b_{H S, t}$ in this case.

The equation above implies that, even when short rates are kept constant (e.g., at the zero lower bound), the long rate can be altered with asset purchase policies. Particularly, LSAPs in the domestic economy lower the supply of long-term bonds, and, in return, increase the supply of short-term bonds through the consolidated government budget constraint 8 When quantities involved are large, this can lower the yields on long-term bonds, and affect aggregate demand even when short rates are constant. The portfolio preference specification in our representative-agent framework is crucial for this result, since, now, the representative agent's marginal utility depends not only on the short-term interest rate, but also on bond quantities. To see this, observe that the first-order condition for short-term domestic bonds (equation $(13)$ ), yields the following expression after log-linearization:

$$
\widehat{\lambda}_{t}=\beta \frac{R}{\pi}\left(E_{t} \widehat{\lambda}_{t+1}+\widehat{R}_{t}-E_{t} \widehat{\pi}_{t+1}\right)+\left(1-\beta \frac{R}{\pi}\right)\left[\left(\frac{1}{\lambda_{S}}-\frac{1}{\lambda_{a}}\right) \widehat{a}_{S, t}+\left(\frac{1}{\lambda_{a}}-1\right) \widehat{a}_{t}-\frac{1}{\lambda_{S}} \widehat{b}_{H S, t}\right],
$$

which reduces to the following when all portfolio elasticities are set to 1 :

$$
\widehat{\lambda}_{t}=\beta \frac{R}{\pi}\left(E_{t} \widehat{\lambda}_{t+1}+\widehat{R}_{t}-E_{t} \widehat{\pi}_{t+1}\right)-\left(1-\beta \frac{R}{\pi}\right) \widehat{b}_{H S, t} .
$$

In the absence of the portfolio choice term in preferences, $\beta R / \pi$ would be equal to 1 at the steady state, and the equation above would become the standard IS curve; thus, aggregate demand would depend only on the current and expected future real short-term interest rates. With our portfolio specification in preferences, the marginal benefit of holding short-term bonds diminishes as short-term bond holdings increase; this in turn stimulates aggregate demand even when short rates are constant. In particular, our portfolio specification allows for changes in the outstanding quantity of bonds to affect demand even in a representative-agent framework, unlike papers in the literature which rely on transaction costs in trading long-term bonds and segmented markets (see, for example, Andres et al., 2004, and Chen et al., 2012a). In these papers, the presence of transaction costs leads to a term premium between long-term and short-term bonds; however, a representative agent can bypass these costs completely by relying only on short-term bonds to smooth

\footnotetext{
${ }^{8}$ This is akin to balance-sheet policies of a central bank, which buys long-term bonds by increasing its short-term liabilities, namely, the monetary base.
} 
consumption. Therefore, these models need to introduce a separate type of agent that can only save through long-term bonds to ensure that the long-term rate has real implications for the aggregate economy. In the absence of these restricted agents in these set-ups, the IS curve determining aggregate demand would depend only on short-term rates, and not on the quantities of bonds outstanding.

Given our calibration in section 3, the coefficient in front of the bond quantity term in equation 20, $1-\beta R / \pi$, is rather small (less than $1 \%$ ). Thus, for the channel emphasized in our paper to be quantitatively important, the supply of short-term bonds needs to change by a significant amount. During an LSAP, a large increase in the outstanding quantity of short-term bonds lowers the willingness of agents to hold these bonds, and stimulates aggregate demand through the "short IS" relationship in equation 200. Note that the "long IS" relationship in equation (14) is also satisfied, where lower long-term interest rates stimulate aggregate demand through this relationship.

In the ROW economy, the term premium on long-term yields is determined by relative holdings of both U.S. and ROW bonds (see equation (15)). Assuming that $\lambda_{S}=\lambda_{L}$ as in our baseline calibration, we can rewrite $\widehat{T}_{t}$ as follows:

$$
\widehat{T}_{t}=\left(\frac{1}{\lambda_{a}}-\frac{1}{\lambda_{L}}\right)\left(\widehat{a}_{L, t}-\widehat{a}_{S, t}\right)+\frac{1}{\lambda_{L}}\left(\widehat{b}_{H L, t}-\widehat{b}_{H S, t}\right) .
$$

The first expression in the above equation represents the effects from portfolio balancing between short- and long-term bond subportfolios, while the second represents the additional effects coming from relative holdings of domestic short- and long-term bonds. Following QE in the United States, ROW residents lower their holdings of long-term U.S. bonds and increase their holdings of short-term U.S. bonds, thereby decreasing the share of their long-term bonds in the aggregate ROW portfolio. Assuming that the ROW government does not change its supply of domestic bonds, the decrease in the long-term bond holdings relative to the short-term bond subportfolio would lower the term premium in the ROW when $\lambda_{a}<\lambda_{L}=\lambda_{S}$. Intuitively, as long as the elasticity of substitution between domestic and foreign bonds is larger than the elasticity of substitution between short- and long-term bonds, the decline in the holdings of long-term U.S. bonds is associated with an increase in the demand for long-term ROW bonds, and the increase in higher holdings of short-term U.S. bonds is associated with a decrease in the demand for short-term ROW bonds. The increased demand for ROW long-term bonds relative to ROW short-term bonds drives up long-term bond prices and lowers the term premium and long-term bond yields in the ROW.

Figure 3 summarizes the equilibria in the U.S. and the ROW bond markets using relative bond demand and supply schedules. The x-axes denote the quantity of short-term bonds relative to the quantity of longterms in the respective bond market, while the y-axes denote the term premium. The relative demand for short-term bonds is downward sloping due to imperfect substitution between short- and long-term bonds. The relative demand schedule for the ROW can be seen as an illustration of the aforementioned expression, 
$\widehat{T}_{t}$, with changes in foreign bond quantities shifting this schedule upward or downward. In addition, relative bond supplies are assumed to be controlled by the government in each region. The left panel in Figure 3 presents the movements in the U.S. term premium following QE in the United States. QE increases the relative supply of short-term bonds and lowers the term premium on the U.S. long-term bonds. Both U.S. and ROW residents start holding relatively more short-term U.S. bonds than long-term U.S. bonds. The right panel shows the effects of the increased relative short-term U.S. bonds on the ROW term premium. On the one hand, the relative demand for ROW short-term bonds shifts downward as ROW agents compensate for the decline in the share of long-term bonds in their overall portfolio, whose magnitude depends on the extent of imperfect substitution between short- and long-term bonds, $\lambda_{a}$. On the other hand, the increased holdings of short-term U.S. bonds and the decreased holdings of long-term U.S. bonds shifts the relative demand for ROW short-term bonds upward due to the imperfect substitution between domestic and foreign assets. A sufficiently low $\lambda_{L}$ (i.e., if agents do not prefer to deviate much from the steady-state ratio of domestic to foreign assets in their long-term bond subportfolio) would cancel out the incentives to substitute away from long-term U.S. bonds, and would in fact increase the term premium in the ROW. This offsetting effect is smaller as domestic and foreign assets become more substitutable, thereby increasing the net demand for long-term ROW bonds and lowering the term premium. Thus, the term premium in the ROW may decrease or increase depending on the portfolio elasticities; with our baseline calibration, we have $\lambda_{a}<\lambda_{L}=\lambda_{S}$, and therefore the term premium and long-term yields in the ROW decline following QE in the United States.

\subsubsection{Short-term and long-term UIP conditions}

The effects of LSAPs on exchange rates can be illustrated by considering the optimality conditions of ROW households with respect to foreign short- and long-term bonds:

$$
\begin{aligned}
& \operatorname{rer}_{t} \lambda_{t}=\beta E_{t}\left[\lambda_{t+1} \operatorname{rer}_{t+1} \frac{R_{t}^{*}}{\pi_{t+1}^{*}}\right]+\frac{\xi_{a}}{a_{t}} \frac{\partial a_{t}}{\partial a_{S, t}} \frac{\partial a_{S, t}}{\partial b_{F S, t}} \\
& \operatorname{rer}_{t} q_{L, t}^{*} \lambda_{t}=\beta E_{t}\left[\lambda_{t+1} \operatorname{rer}_{t+1} \frac{1+\kappa q_{L, t+1}^{*}}{\pi_{t+1}^{*}}\right]+\frac{\xi_{a}}{a_{t}} \frac{\partial a_{t}}{\partial a_{L, t}} \frac{\partial a_{L, t}}{\partial b_{F L, t}},
\end{aligned}
$$

where $b_{F S, t}=B_{F S, t} / P_{t}^{*}, b_{F L, t}=B_{F L, t} / P_{t}^{*}$, and $\operatorname{rer}_{t}=e_{t} P_{t}^{*} / P_{t}$ denotes the real exchange rate. The firstorder conditions for short-term domestic and foreign bonds can be combined to yield a short-term uncovered interest parity (UIP) condition. After log-linearization, this short-term UIP condition can be written as

$$
\widehat{R}_{t}-\widehat{R}_{t}^{*}=E_{t} \widehat{d}_{t+1}+\left(\frac{1-\beta \frac{R}{\pi}}{\beta \frac{R}{\pi}}\right) \frac{1}{\lambda_{S}}\left[\widehat{b}_{H S, t}-\left(\widehat{\operatorname{rer}}_{t}+\widehat{b}_{F S, t}\right)\right],
$$

where $\widehat{d}_{t}=\widehat{e}_{t}-\widehat{e}_{t-1}$ denotes the nominal depreciation rate of the ROW currency. The above condition implies that the country risk premium is determined by the relative holdings of short-term domestic and foreign bonds. Thus, even when the short-term rate differentials cannot change due to the zero lower bound, 
LSAPs can still affect the exchange rate through the country risk premium. More generally, equation 24 can be interpreted as the relative demand schedule between short-term U.S. and ROW bonds. Following QE in the United States, ROW holdings of short-term U.S. bonds would increase relative to their holdings of shortterm ROW bonds, thereby increasing the share of U.S. bonds in the ROW residents' short-term subportfolio. Higher relative holdings of short-term U.S. bonds in the ROW economy would thus put downward pressure on the ROW short-term interest rates and appreciate on the ROW currency 9 As these bonds become more substitutable (i.e., as $\lambda_{S}$ increases), the appreciation effects on the ROW currency become more muted; conversely, as $\lambda_{S}$ converges to zero, LSAPs would lead to a larger appreciation of the ROW currency.

The long-term UIP condition can be obtained by combining the first-order conditions of ROW households with respect to long-term domestic and foreign bonds as

$$
\begin{aligned}
\frac{R_{L}}{R_{L}-\kappa}\left(\widehat{R}_{L, t}-\right. & \left.\widehat{R}_{L, t}^{*}\right)-\frac{\kappa}{R_{L}-\kappa}\left(E_{t} \widehat{R}_{L, t+1}-E_{t} \widehat{R}_{L, t+1}^{*}\right) \\
& =E_{t} \widehat{d}_{t+1}+\left(\frac{1-\beta \frac{R}{\pi}}{\beta \frac{R}{\pi}}\right) \frac{1}{\lambda_{L}}\left[\widehat{q}_{L, t}+\widehat{b}_{H L, t}-\left(\widehat{r e r}_{t}+\widehat{q}_{L, t}^{*}+\widehat{b}_{F L, t}\right)\right]
\end{aligned}
$$

which implies that the appreciation of the ROW currency also depends on the long-term interest rate differential and the relative holdings of domestic and foreign long-term bonds. Note that, now, the expression governing relative holdings in equation 25] will tend to move in the opposite direction of that of the shortterm UIP. In particular, following QE in the United States, ROW households would like to increase their domestic long-term bond holdings (which, nevertheless, would stay the same in equilibrium due to their constant supply in the absence of $\mathrm{QE}$ in the ROW) relative to their long-term U.S. bond holdings. Thus, the long-term interest rate differential, $R_{L, t}-R_{L, t}^{*}$, would increase. Most of this adjustment is due to the larger decline in U.S. long-term rates, however; thus, the long-term UIP condition still validates a small decline in ROW long-term rates, as well as an appreciation in the ROW currency. As we further discuss in section 5, the spillover effects of LSAPs on ROW long-term yields and the exchange rate depend importantly on the substitutability between domestic and foreign long-term bonds in the ROW portfolio. As $\lambda_{L}$ increases, domestic and foreign long-term bonds become more substitutable, and the ROW long-term rates decline, more closely mirroring the fall in the U.S. long-term rates. Conversely, as $\lambda_{L}$ approaches 0 , the ROW long-term rates decline less, or can even increase; the latter can happen with a low enough $\lambda_{L}$, since the right-hand side of the long-term UIP condition becomes very responsive to changes in the relative long-term bond holdings, and increases sharply, as a result of QE.

The maturity composition of steady-state U.S. bond holdings in the ROW also plays an important role in determining the magnitude of QE spillovers. Consider a case where the ROW's U.S. bond portfolio is more

\footnotetext{
${ }^{9}$ In our baseline simulations, we assume that the short-term interest rate in the ROW economy is not bounded by the zero lower bound following the QE shock in the U.S. economy. The resulting decline in ROW policy rates thus partly cushions the appreciation effects on the ROW currency. This appreciation effect would be larger if the ROW economy was also constrained by the zero lower bound during this period.
} 
skewed toward long-term U.S. bonds, with their total U.S. portfolio the same as before. Since the steady-state share of U.S. bonds in their short-term bond subportfolio is now smaller, the same amount of QE in percentage terms would increase their relative holdings of short-term U.S. bonds further, which would result in a larger appreciation of the ROW currency through the short-term UIP (see equation (24)). Note that the long-term UIP condition would also validate the higher appreciation of the ROW currency in equilibrium. Since the steady-state share of long-term U.S. bonds is now larger in the long-term bond subportfolio, the percentage change in the relative U.S. long-term bonds would be smaller; therefore, the dampening effect mentioned above in the long-term UIP condition coming from the relative bond holdings would also be smaller. As a result, ROW long-term rates fall more, along with a larger appreciation of the ROW currency. Furthermore, as we discuss in the quantitative section, higher appreciation would increase disinflationary pressures, and lead to lower policy rates in the ROW. Therefore, international spillovers would increase when ROW residents' holdings of U.S. bonds are more weighted toward long-term bonds.

\subsection{Final-goods aggregators}

There are two types of final-goods aggregators; for consumption goods, $c_{t}$, and for investment goods, $i_{t}$. In what follows, we mainly describe the consumption-goods aggregators, but investment-goods aggregators are modelled in an analogous fashion.

Consumption aggregators are perfectly competitive, and they produce the final goods as a CES aggregate of home and foreign goods, $c_{h, t}$ and $c_{f, t}$ :

$$
c_{t}=\left[\gamma_{c}^{\frac{1}{\lambda_{c}}} c_{h, t}^{\frac{\lambda_{c}-1}{\lambda_{c}}}+\left(1-\gamma_{c}\right)^{\frac{1}{\lambda_{c}}} c_{f, t}^{\frac{\lambda_{c}-1}{\lambda_{c}}}\right]^{\frac{\lambda_{c}}{\lambda_{c}-1}}
$$

where $\gamma_{c}$ denotes the share of domestic goods, and $\lambda_{c}$ is the elasticity of substitution between home and foreign goods, in the consumption aggregate. For any level of aggregate consumption, their optimal demand for the domestic and imported consumption goods is given by

$$
c_{h, t}=\left(\frac{P_{h, t}}{P_{t}}\right)^{-\lambda_{c}} \gamma_{c} c_{t}, \text { and } c_{f, t}=\left(\frac{P_{f, t}}{P_{t}}\right)^{-\lambda_{c}}\left(1-\gamma_{c}\right) c_{t},
$$

where $P_{h, t}$ and $P_{f, t}$ are the prices of the home and foreign goods, respectively. The aggregate price index for consumption goods is given by

$$
P_{t}=\left[\gamma_{c} P_{h, t}^{1-\lambda_{c}}+\left(1-\gamma_{c}\right) P_{f, t}^{1-\lambda_{c}}\right]^{\frac{1}{1-\lambda_{c}}}
$$


The analogous expressions for investment-goods aggregators are given by

$$
\begin{aligned}
& i_{t}=\left[\gamma_{i}^{\frac{1}{\lambda_{i}}} i_{h, t}^{\frac{\lambda_{i}-1}{\lambda_{i}}}+\left(1-\gamma_{i}\right)^{\frac{1}{\lambda_{i}}} i_{f, t}^{\frac{\lambda_{i}-1}{\lambda_{i}}}\right]^{\frac{\lambda_{i}}{\lambda_{i}-1}}, \\
& i_{h, t}=\left(\frac{P_{h, t}}{P_{i, t}}\right)^{-\lambda_{i}} \gamma_{i} i_{t} \text { and } i_{f, t}=\left(\frac{P_{f, t}}{P_{i, t}}\right)^{-\lambda_{i}}\left(1-\gamma_{i}\right) i_{t}, \\
& P_{i, t}=\left[\gamma_{i} P_{h, t}^{1-\lambda_{i}}+\left(1-\gamma_{i}\right) P_{f, t}^{1-\lambda_{i}}\right]^{\frac{1}{1-\lambda_{i}}},
\end{aligned}
$$

where $P_{i, t}$ denotes the price of the aggregate investment good.

\subsection{Domestic firms}

There is a unit measure of monopolistically competitive domestic firms indexed by $j$. Their technology is described by the following production function:

$$
y_{t}(j)=\left[u_{t}(j) k_{t-1}(j)\right]^{\alpha}\left[n_{t}(j)\right]^{1-\alpha}-f,
$$

where $\alpha$ is the share of capital, $u_{t}$ is the capital utilization rate, and $f$ is a fixed cost of production 10

Domestic goods produced are heterogeneous across firms, and are aggregated into a homogeneous domestic good by perfectly-competitive final-goods producers using a standard Dixit-Stiglitz aggregator. The demand curve facing each firm is given by

$$
y_{t}(j)=\left(\frac{P_{h, t}(j)}{P_{h, t}}\right)^{-\Theta_{h}} y_{t}
$$

where $y_{t}$ is aggregate domestic output, and $\Theta_{h}$ is the elasticity of substitution between differentiated goods, implying a steady-state gross markup of price over the marginal cost of $\theta_{h}=\Theta_{h} /\left(\Theta_{h}-1\right)$.

Firm $j$ 's profits at period $t$ are given by

$$
\begin{aligned}
\frac{\Pi_{h, t}(j)}{P_{t}}= & \frac{P_{h, t}(j)}{P_{t}} y_{t}(j)-\frac{W_{t}}{P_{t}} n_{t}(j)-r_{k, t} k_{t-1}(j) \\
& -\frac{\kappa_{u}}{1+\varpi}\left[u_{t}(j)^{1+\varpi}-1\right] k_{t-1}(j)-\frac{\kappa_{p h}}{2}\left(\frac{P_{h, t}(j) / P_{h, t-1}(j)}{\pi_{h, t-1}^{\varsigma_{h}} \pi^{1-\varsigma_{h}}}-1\right)^{2} \frac{P_{h, t}}{P_{t}} y_{t},
\end{aligned}
$$

where $\kappa_{u}$ and $\varpi$ are the level and elasticity parameters for the utilization cost. Similar to wage stickiness, price stickiness is introduced via quadratic adjustment costs with level parameter $\kappa_{p h}$, and $\varsigma_{h}$ captures the extent to which price adjustments are indexed to past inflation.

A domestic firm's objective is to choose the quantity of inputs and output, and the price of its output each period, to maximize the present value of profits (using the households' stochastic discount factor) subject to the demand function it is facing with respect to its individual output from the aggregators. The first-order

\footnotetext{
${ }^{10}$ The fixed-cost parameter $f$ is set equal to $\theta_{h}-1$ times the steady-state level of detrended output to ensure that pure economic profits are zero at the steady state; hence, there is no incentive for firm entry and exit in the long run.
} 
conditions of the firm with respect to labor and capital can be combined to relate the capital-labor ratio to the relative price of inputs as

$$
\widehat{w}_{t}-\widehat{r}_{k, t}=\widehat{u}_{t}+\widehat{k}_{t-1}-\widehat{n}_{t}
$$

The first-order conditions for capital and utilization can be combined to yield

$$
\widehat{u}_{t}=\frac{1}{\varpi} \widehat{r}_{k, t} .
$$

Finally, the first-order condition with respect to price yields the New Keynesian Phillips curve in domestic prices as

$$
\widehat{\pi}_{h, t}=\frac{\varsigma_{h}}{1+\varsigma_{h} \beta} \widehat{\pi}_{h, t-1}+\frac{\beta}{1+\varsigma_{h} \beta} E_{t} \widehat{\pi}_{h, t+1}-\frac{\Theta_{h}-1}{\left(1+\varsigma_{h} \beta\right) \kappa_{p h}}\left[\widehat{p}_{h, t}+z_{t}+\alpha\left(\widehat{u}_{t}+\widehat{k}_{t-1}-\widehat{n}_{t}\right)-\widehat{w}_{t}\right],
$$

where $p_{h, t}=P_{h, t} / P_{t}$ is the relative price of home goods.

\subsection{Importers}

There is a unit measure of monopolistically competitive importers indexed by $j$. They import foreign goods from abroad, differentiate them and markup their price, and then sell these heterogeneous goods to perfectly competitive import aggregators, who aggregate these into a homogeneous import good using a standard Dixit-Stiglitz aggregator. The demand curve facing each importer is given by

$$
y_{f, t}(j)=\left(\frac{P_{f, t}(j)}{P_{f, t}}\right)^{-\Theta_{f}} y_{f, t}
$$

where $y_{f, t}$ is aggregate imports, and $\Theta_{f}$ is a time-varying elasticity of substitution between the differentiated goods, implying a steady-state gross markup of the domestic price of imported goods over its import price of $\theta_{f}=\Theta_{f} /\left(\Theta_{f}-1\right)$.

Importers maximize the present value of profits (using the households' stochastic discount factor) subject to the demand function they are facing from the aggregators with respect to their own output. The importer's profits at period $t$ are given by

$$
\frac{\Pi_{f, t}(j)}{P_{t}}=\frac{P_{f, t}(j)}{P_{t}} y_{f, t}(j)-\frac{e_{t} P_{h, t}^{*}}{P_{t}} y_{f, t}(j)-\frac{\kappa_{p f}}{2}\left(\frac{P_{f, t}(j) / P_{f, t-1}(j)}{\pi_{f, t-1}^{\varsigma_{f}} \pi^{1-\varsigma_{f}}}-1\right)^{2} \frac{P_{f, t}}{P_{t}} y_{f, t}
$$

where $\kappa_{p f}$ and $\varsigma_{f}$ are the price adjustment cost and indexation parameters, respectively. These import pricestickiness features ensure that exchange rate movements do not immediately pass through to the domestic price of imported goods.

The first-order condition of importers with respect to price yields the import price New Keynesian Phillips 
curve (after log-linearization):

$$
\widehat{\pi}_{f, t}=\frac{\varsigma_{f}}{1+\varsigma_{f} \beta} \widehat{\pi}_{f, t-1}+\frac{\beta}{1+\varsigma_{f} \beta} E_{t} \widehat{\pi}_{f, t+1}-\frac{\Theta_{f}-1}{\left(1+\varsigma_{f} \beta\right) \kappa_{p f}}\left(\widehat{p}_{f, t}-\widehat{r e r}_{t}-\widehat{p}_{h, t}^{*}\right)
$$

where $\pi_{f, t}=P_{f, t} / P_{f, t-1}$ is the import price inflation factor, and $p_{f, t}=P_{f, t} / P_{t}$ is the relative price of imported goods.

The balance-of-payments identity in the model is given by

$$
\begin{aligned}
& \left(\frac{e_{t} B_{F S, t}}{P_{t}}-\frac{e_{t} R_{t-1}^{*} B_{F S, t-1}}{P_{t}}\right)+\left(\frac{e_{t} q_{L, t}^{*} B_{F L, t}}{P_{t}}-\frac{e_{t} R_{L, t}^{*} q_{L, t}^{*} B_{F L, t-1}}{P_{t}}\right) \\
& \quad-\left(\frac{B_{F S, t}^{*}}{e_{t} P_{t}}-\frac{R_{t-1} B_{F S, t-1}^{*}}{e_{t} P_{t}}\right)-\left(\frac{q_{L, t} B_{F L, t}^{*}}{e_{t} P_{t}}-\frac{R_{L, t} q_{L, t} B_{F L, t-1}^{*}}{e_{t} P_{t}}\right)=\frac{P_{h, t}}{P_{t}} y_{f, t}^{*}-\frac{e_{t} P_{h, t}^{*}}{P_{t}} y_{f, t} .
\end{aligned}
$$

\subsection{Capital producers}

Capital producers are perfectly competitive. After goods production takes place, these firms purchase the undepreciated part of the installed capital from entrepreneurs at a relative price of $q_{t}$, and the new capital investment goods from final-goods firms at a price of $P_{i, t}$, and produce the capital stock to be carried over to the next period. This production is subject to adjustment costs in the change in investment, and is described by the following law of motion for capital:

$$
k_{t}=(1-\delta) k_{t-1}+\left[1-\frac{\varphi}{2}\left(\frac{i_{t}}{i_{t-1}}-1\right)^{2}\right] i_{t},
$$

where $\varphi$ is the adjustment cost parameter.

After capital production, the end-of-period installed capital stock is sold back to entrepreneurs at the installed capital price of $q_{t}$. The capital producers' objective is thus to maximize

$$
E_{0} \sum_{t=0}^{\infty} \beta^{t} \frac{\lambda_{t}}{\lambda_{0}}\left[q_{t} i_{t}-q_{t} \frac{\varphi}{2}\left(\frac{i_{t}}{i_{t-1}}-1\right)^{2} i_{t}-\frac{P_{i, t}}{P_{t}} i_{t}\right],
$$

subject to the law of motion for capital, where future profits are discounted using the patient households' stochastic discount factor. The first-order condition of capital producers with respect to investment yields the following investment demand equation (after log-linearization):

$$
\widehat{i}_{t}-\widehat{i}_{t-1}=\beta E_{t}\left[\widehat{i}_{t+1}-\widehat{i}_{t}\right]+\frac{1}{\varphi}\left(\widehat{q}_{t}-\widehat{p}_{i, t}\right)
$$

where $p_{i, t}=P_{i, t} / P_{t}$ is the relative price of investment goods. 


\subsection{Monetary and fiscal policy}

The central bank targets the nominal interest rate using a Taylor rule:

$$
\log R_{t}=\rho \log R_{t-1}+(1-\rho)\left(\log R+r_{\pi} \log \frac{\pi_{t}}{\pi}+r_{y} \log \frac{y_{t}}{y}+r_{\Delta y} \log \frac{y_{t}}{y_{t-1}}\right)+\varepsilon_{r, t}
$$

where $R$ is the steady-state value of the (gross) nominal policy rate, $\rho$ determines the extent of interest rate smoothing, and the parameters $r_{\pi}, r_{y}$, and $r_{\Delta y}$ determine the importance of inflation, the output gap and output growth in the Taylor rule, respectively. $y$ is the detrended steady-state level of output, and $\varepsilon_{r, t}$ is a monetary policy shock which follows an $\mathrm{AR}(1)$ process.

The consolidated government budget constraint is given by

$$
p_{h, t} g_{t}+\frac{R_{t-1}}{\pi_{t}} b_{S, t-1}+\frac{R_{L, t}}{\pi_{t}} q_{L, t} b_{L, t-1}=\frac{T A X_{t}}{P_{t}}+b_{S, t}+q_{L, t} b_{L, t},
$$

where $b_{S, t}$ and $b_{L, t}$ represent real short- and long-term government debt, respectively. Lump-sum taxes adjust with the level of government debt to rule out a Ponzi scheme for the government:

$$
\frac{T A X_{t}}{P_{t}}=\Xi y\left(\frac{y_{t}}{y}\right)^{\tau_{y}}\left(\frac{b_{S, t-1}+q_{L, t-1} b_{L, t-1}}{b_{S}+q_{L} b_{L}}\right)^{\tau_{b}},
$$

where $\Xi$ is a level parameter, and $\tau_{y}$ and $\tau_{b}$ determine the response of taxes to output and government debt.

Finally, government controls the supply of long-term bonds in real terms following an $\operatorname{AR}(1)$ process:

$$
\log \left(q_{L, t} b_{L, t}\right)=\left(1-\rho_{b}\right) \log \left(q_{L} b_{L}\right)+\rho_{b} \log \left(q_{L, t} b_{L, t-1}\right)+\varepsilon_{b, t},
$$

where $\rho_{b}$ governs the persistence of long-term bonds, and $\varepsilon_{b, t}$ represents the unconventional monetary policy shock (i.e., QE shock) in the model.

\subsection{Market clearing conditions}

The domestic goods are used in the final-goods production for consumption, investment, government expenditure and exports ${ }^{11}$

$$
c_{h, t}+i_{h, t}+g_{t}+y_{f, t}^{*}=y_{t} .
$$

Similarly, the imported goods are used only for consumption and investment; hence,

$$
c_{f, t}+i_{f, t}=y_{f, t} .
$$

The model's equilibrium is defined as prices and allocations such that households maximize the discounted

\footnotetext{
${ }^{11}$ Note that utilization costs are assumed to accrue to households in lump-sum fashion, and therefore do not enter the feasibility condition.
} 
present value of utility, and all firms maximize the discounted present value of profits, subject to their constraints, and all markets clear.

\section{Calibration}

In our benchmark calibration, we set the structural parameters of both countries to equal values, except for the portfolio and labor level parameters in preferences, as well as the level parameter in the tax policy function ${ }^{12}$ We calibrate the parameters using steady-state relationships in the model and U.S. data from the National Income and Product Accounts (NIPA; Bureau of Economic Analysis) and the Flow of Funds Accounts (FOF; Federal Reserve Board) averaged over the post-war period ${ }^{13}$ We first discuss the choice of parameters governing portfolios and preferences, followed by parameters related to technology and government policy. A list of parameter values is given in Table 1.

Portfolios. We assume that only U.S. bonds are traded internationally; therefore, the shares of domestic assets in the U.S. short- and long-term portfolios, $\gamma_{S}^{*}$ and $\gamma_{L}^{*}$, are both set to 1 . We calibrate the share of short-term bonds in the U.S. portfolio, $\gamma_{a}^{*}$, to 0.66 based on U.S. residents' relative holdings of short-term government liabilities (see Figure 2). Here, short-term government liabilities include privately held marketable U.S. Treasury securities with a remaining maturity of less than one year and the monetary base (i.e., financial institutions' reserves at the Federal Reserve System, vault cash and currency outside banks) as in Chen et al. (2012a) ${ }^{14}$ The monetary base is included since it is a perfect substitute for short term Treasury bills at the zero lower bound.

To obtain the share parameters in the ROW portfolio, we first consider their domestic-to-foreign bond ratio to be 0.75 , based on the facts documented in Coeurdacier and Rey (2013). We also assume that ROW agents hold domestic bonds in short-term maturities by the same fraction that U.S. residents hold short-term bonds in their portfolio; thus, $66 \%$ of ROW domestic bonds are assumed to be held in short-term maturities. We use these figures to calculate the domestic shares in the ROW short- and long-term subportfolios and the share of short-term bonds in the ROW overall portfolio. Thus, $\gamma_{S}$ and $\gamma_{L}$ are set to 0.85 and 0.62 , respectively. Note that $\gamma_{L}$ is smaller than $\gamma_{S}$, reflecting a larger share of ROW holdings of U.S. long-term bonds relative to short-term ones in the data. Finally, the implied share of short-term bonds in the ROW overall portfolio, $\gamma_{a}$, is set to 0.59 .

We calibrate the elasticity of substitution between short- and long-term bonds based on the portfolio

\footnotetext{
${ }^{12} \mathrm{~A}$ non-zero net foreign asset position requires these parameters to be different across regions (see Table 1).

${ }^{13}$ For portfolio parameters, we use data averaged over 2000-2010, as in Figure 2 reflecting more recent government bond supply and international developments in financial markets.

${ }^{14} \mathrm{FOF}$ data report holdings of U.S. Treasury securities with the original maturity. We adjust these so that short-term holdings include long-term securities with a remaining maturity of less than one year, using Treasury data on the maturity of privately-held Treasury securities. When distributing long-term securities with a remaining maturity of less than one year to ROW and U.S. residents, we use the weights in holdings of Treasury bills (i.e., original maturity of less than one year) from FOF tables.
} 
balance estimates in Gagnon et al. (2011). In particular, our calibrated value $\lambda_{a}=2$ implies about a 4 bps reduction in the 10-year yields in the U.S. economy following a $\$ 100$ billion asset purchase in the United States, consistent with the average value of their estimates ${ }^{15}$ For the elasticity of substitution between domestic and foreign assets, we combine the short- and long-term UIP conditions (see equations 24) and 25) assuming that $\lambda_{S}$ and $\lambda_{L}$ are equal to each other, and regress the deviations from UIP (i.e., the difference between the nominal depreciation rate and the lagged interest rate differential) on the share of foreign bonds in the ROW portfolio. The data on domestic and foreign debt securities come from the Bank for International Settlements (BIS), the sample period is 1989Q4-2013Q4, and the ROW data capture all countries except the United States. The policy rate in the ROW and the exchange rate are constructed using the weighted average of data from G-20 countries excluding the United States. The regression implies that a 1 pp increase in foreign bond holdings in the ROW portfolio generates about a 1 bp drop in UIP deviations ${ }^{16}$ The corresponding value for the portfolio elasticity parameters is $\lambda_{S}=\lambda_{L}=3.4$.

We use the aforementioned values for the portfolio share and elasticity parameters in our baseline calibration, but we also conduct a sensitivity analysis on these parameters in section 5. Finally, the coupon rate on long-term bonds, $\kappa$, is calibrated to imply a duration of 30 quarters, similar to the average duration of long-term U.S. Treasury securities outstanding in the secondary market.

Preferences. We calibrate the time discount factor, $\beta$, to match a target capital-output ratio, $k / y$, of 10, using the optimality condition for household's capital decision at the steady state. Traditionally, the discount factor is calibrated to match the steady-state interest rate using the first-order condition on shortterm bonds. We instead use this condition to calibrate the portfolio level coefficient, $\xi_{a}$, in preferences using the ratio of government bond holdings to GDP, $a / y$; thus, we set $\xi_{a}$ to 0.04 and 0.05 in the U.S. and the ROW economies, respectively. Since the ROW holds a higher level of government assets as a proportion of its output, its portfolio level coefficient is calculated to be slightly larger than in the United States. We set the habit parameter, $\zeta$, to 0.70, close to values found in Smets and Wouters (2007) and Adolfson et al. (2008). The inverse of the Frisch elasticity of labor supply, $\vartheta$, is set to 1 . This value is in line with the estimates presented in Blundell and MaCurdy (1999), and represents a compromise between the estimates in the real business cycle and New Keynesian literatures (Smets and Wouters, 2007). The labor level parameter, $\xi_{n}$, is calibrated to match the working hours of the economically active population as a ratio of total non-sleeping hours of $32 \% 17$

Technology. We calibrate the capital share in home-goods production, $\alpha$, to 0.34 in order to match a

\footnotetext{
${ }^{15}$ This also falls within the range of estimates reported in Bernanke (2012) regarding the fall in long-term yields due to LSAP2.

${ }^{16}$ The small estimate from this regression is consistent with empirical studies finding high elasticity of substitution between home and foreign assets (see, for example, Lewis, 1995).

${ }^{17} \mathrm{~A}$ non-zero trade balance requires the consumption-output ratio or the investment-output ratio to be different in the two regions, when the same home-bias parameters are assumed in both regions' aggregator functions. We choose, $c / y$, to be different across regions, which also implies a different labor level coefficient in preferences.
} 
labor income share of $66 \%$. The depreciation rate of capital, $\delta$, is calibrated to match an investment-output ratio, $i / y$, of $19 \%$. Home-bias parameters in the consumption and investment aggregators, $\gamma_{c}$ and $\gamma_{i}$, are both set to 0.9. Elasticity of substitution parameters in these aggregators are similar to those used in the New Keynesian DSGE literature (see Gertler et al., 2007). Similarly, the markup and indexation parameters in the labor and goods markets (both for domestic producers and importers) are set using corresponding values in the literature 18

Adjustment cost parameters on prices and wages, $\kappa_{p h}, \kappa_{p f}, \kappa_{w}$, are calibrated so that the resulting New Keynesian Phillips curves have slopes equivalent to assuming Calvo probabilities of 0.9 and 0.85 for wages and prices, respectively. The investment adjustment cost parameter, $\varphi$, is calibrated so that investment is 2.5 times more volatile than output with a standard monetary policy shock. The capacity utilization elasticity, $\varpi$, is set to 0.12 , while the utilization cost level parameter, $\kappa_{u}$, is calibrated to imply a unit utilization rate at the steady state without loss of generality.

Government Policy. Taylor rule parameters are set to values close to those found in the literature (see Smets and Wouters, 2007, and Adolfson et al., 2008). The interest rate smoothing parameter, $\rho$, is set to 0.75 , and the inflation response coefficient, $r_{\pi}$, is set to 1.75 . The literature typically finds small response coefficients for the output gap and output growth. Thus, we set these to 0.05 in our benchmark calibration. We set the elasticity parameters in the tax function, $\tau_{y}$ and $\tau_{b}$, large enough to ensure a sustainable debt path (see Chen et al., 2012a), while making sure that debt converges within 10 years. The tax level parameters in the two countries, $\Xi$ and $\Xi^{*}$, are set to ensure that each government's budget constraint is satisfied given the bond ratios and interest rates at the steady state 19

\section{Results}

In this section, we first use our model to evaluate the impact of QE on both the U.S. and the ROW economies. We then compare the spillover effects of conventional monetary policy in the United States to the ROW with those from a QE shock originating in the United States 20

\subsection{The impact of a QE shock}

The QE shock is calibrated to match a $\$ 600$ billion drop in the privately-held long-term U.S. government bonds, similar to the purchase amount announced for LSAP2 in the last quarter of 2010. Following Chen

\footnotetext{
${ }^{18}$ Note that we have conducted a sensitivity analysis using different values for these parameters. Their effect on key results is only modest compared to the portfolio parameters.

${ }^{19}$ Note that these tax parameters have to be different across the two regions to match a non-zero trade balance, since we have different consumption-output ratios. The resulting government-output ratios are $17 \%$ and $18 \%$ for the ROW and the United States, and the tax level parameters are 0.17 and 0.19 for the ROW and the United States, respectively.

${ }^{20}$ We use a first-order approximation of the model to obtain our results, and use IRIS routines for all simulations (Benes et al. 2013b).
} 
et al. (2012a), we assume no change in the U.S. policy rate for four quarters following the asset purchase announcement, after which the central bank keeps its balance-sheet size constant for eight quarters, and then gradually sells these bonds over the next eight quarters. The assumption of no change in the short-term rate in the first four quarters following the LSAP announcement is consistent with interest rate expectations in the Blue Chip survey conducted in 2011 (Chen et al., 2012a). Note that the whole path of the aforementioned QE policy is known by all agents at the impact period 21

Figure 4 shows the impulse responses of U.S. variables after a QE shock in the United States. Due to imperfect substitution between short- and long-term bonds, the term premium on long-term rates in the United States falls by 30 bps, driving long-term yields down by about 22 bps ${ }^{22}$ Long-term yields fall less than the term premium, since expected future short-term rates (after four quarters) increase as a result of the QE shock, dampening the portfolio balance effect. If agents expect the policy rate to stay constant for more than four quarters, long-term yields would fall even more at impact.

As a result of QE, short-term bond holdings of U.S. residents increase. Higher short-term bond holdings and lower long-term rates stimulate aggregate demand through the short- and long-term IS curves, respectively. Higher aggregate demand leads to an increase in inflation. GDP increases by $0.6 \%$ due to the increase in consumption, investment and net exports, and inflation increases by $0.4 \%$. The trade balance improves mainly due to the increase in exports as a result of the $1.6 \%$ depreciation in the U.S. dollar, while the immediate impact on imports is smaller as the income and price effects move in opposite directions.

The impulse responses of ROW variables to the QE shock in the United States are shown in Figure 5. The international effects of the QE spill over to the other country partly through the short- and long-term UIP conditions. QE generates a cross-country differential in long-term rates at impact, which puts downward pressure on ROW long-term rates (which decreases by slightly more than 4 bps at impact), and appreciation pressures on its currency (which increases by about 1.6\%) through the long-term UIP condition. Note that the resulting appreciation has to satisfy the short-term UIP condition as well. Although short-term rates do not change in the United States, bond quantities matter for the exchange rate and the ROW short-term rate. The relative increase in ROW holdings of short-term U.S. bonds pushes the value of the ROW currency upward, consistent with the direction implied by the long-term UIP condition. As a result, the ROW currency appreciates, which leads to lower inflation in the ROW, which in turn leads to a decline in current and expected

\footnotetext{
${ }^{21}$ In reality, policy rates in the United States stayed at the zero lower bound for much longer than four quarters following the LSAP2 announcement, although this was not expected by most market participants at the time. In our simulations, the policy rate starts to rise after four quarters following QE due to the QE shock's stimulative effects on inflation and output. The effects of QE would be larger, if the policy rate is assumed to stay at the zero lower bound for longer. Given initial expectations on the policy rate path with four quarters at the zero lower bound, one can think of the additional duration at the zero lower bound as negative conventional monetary policy shocks, which get realized in periods following the announcement of QE. We do not measure the effects of these additional surprises in our estimations, and keep the QE experiment as close to Chen et al. (2012a) as possible.

${ }^{22}$ The impact on long-term yields is consistent with findings for LSAP2 from event studies in the literature, which range from -15 bps to -45 bps. See Gagnon et al. (2011), Hamilton and Wu (2012), Krishnamurthy and Vissing-Jorgensen (2011), Meaning and Zhu (2011), D'Amico et al. (2012), and Wright (2012), among others.
} 
short-term (policy) rates in the ROW economy. This effect is quantitatively small, however (compare the magnitudes for the long-term rate and the term premium in the ROW in Figure 5).

The main effect on ROW long-term rates comes through the term premium component. In particular, QE lowers the yields on long-term U.S. bonds, which prompts ROW residents to increase their relative demand for long-term ROW bonds, which in turn leads to a fall in the ROW term premium of about $4 \mathrm{bps}$. ROW long-term rates fall by slightly more than 4 bps due to the fall in current and expected future short-term rates. Note that, since the impact on the ROW long-term rate through the expectations hypothesis is very small, the results on long-term yields would not change much if we had assumed the same zero lower bound environment in the ROW as in the United States (i.e., for four quarters). Thus, ROW countries which are at the zero lower bound would also not be immune from the international spillover effects of QE performed in other large economies.

The decline in short- and long-term rates in the ROW generates an increase in aggregate consumption and investment through the short- and long-term IS equations. Increased demand for consumption and investment goods, along with appreciation of the ROW currency, leads to a larger rise in imports than exports in the ROW. This lowers their net exports, putting negative pressure on the ROW GDP. However, stimulus coming from the domestic channel in the ROW dominates the fall in net exports, and generates an overall increase in output. These quantitative results highlight that QE spillovers from the United States to the ROW occur mainly through financial channels, and not through the trade channel (i.e., not through higher demand for ROW goods in the United States) ${ }^{23}$ The strength of the financial channel depends critically on the elasticity of substitution parameters in the portfolio preference specification, as we show in the next section on sensitivity analysis.

Following QE, the ROW starts to hold more short-term U.S. bonds and fewer long-term U.S. bonds, similar to U.S. residents. The result of increased U.S. short-term bond holdings in the ROW merits some discussion. Note that even though the ROW has a flexible exchange rate regime (i.e., does not conduct any foreign exchange intervention to offset the currency appreciation pressures during the U.S. QE), the imperfect substitution between assets leads the ROW agents to increase short-term U.S. bond holdings. If the ROW had fixed or managed exchange rate regimes, their short-term U.S. bond holdings would need to increase even more following QE. Their long-term rates would thus fall more as well, as a result of a larger decrease in current and expected short-term rates ${ }^{24}$

\footnotetext{
${ }^{23}$ Dahlhaus et al. (2014) empirically show that the financial channel was the predominant factor in the transmission of U.S. QE spillovers to the Canadian economy.

${ }^{24} \mathrm{IMF}$ data indicate that central banks of emerging-market economies (EMEs) tended to increase their U.S.-dollardenominated reserves during $\mathrm{QE}$ episodes, partly to offset the appreciation pressures on their currencies. The quantitative effects of these foreign exchange interventions, and the foreign reserve accumulation that accompanied this type of policy, is beyond the scope of this paper and is left for future research.
} 


\subsection{QE shock versus interest rate shock}

In this subsection, we compare the spillover effects of a QE shock and a conventional interest rate shock in the United States. Both policies result in qualitatively similar spillover effects on the ROW economy (see Figure 6). For our quantitative comparison, we scale the interest rate shock (about a $150 \mathrm{bps}$ cut in the policy rate) to have the same peak output response in the United States with the QE shock described previously (i.e., around $0.6 \%$ of steady-state GDP) 25

In our baseline model, the QE shock leads to a much larger (more than twice as large) spillover effect on ROW economic activity relative to the interest rate shock. The difference results mainly from the fact that portfolio balance effects on the ROW long-term yields are stronger in the case of QE compared to conventional monetary policy. In particular, QE in the United States generates a drop in the ROW term premium as a result of portfolio balancing, whereas this effect is not present in the case of conventional monetary policy. Long-term rates in the ROW also fall with the interest rate shock in the United States, but far less relative to the QE shock. Also note that this decline in the ROW long-term yields is mainly due to the expectations hypothesis (i.e., based on the expected path of the policy rate), and not due to any significant change in the term premium ${ }^{26}$ The decline in short- and long-term interest rates in the ROW stimulates economic activity, more so in the case of QE compared to an interest rate cut in the United States.

Figure 6 also shows that U.S. conventional monetary policy leads to a smaller drop in U.S. long-term yields compared to QE. This is because bond quantity implications of the interest rate shock are not as severe as in the QE policy. Similar to the ROW, the long-term yields in the United States fall mainly due to the expected path of the short-term rate, and not due to any significant change in the term premium. In fact, the term premium increases very slightly due to the decline in short-term bond holdings of U.S. agents. This occurs because the government needs to supply fewer short-term bonds given the decline in its overall interest burden (note that long-term bonds are kept in fixed supply in the absence of QE) ${ }^{27}$

In the next section, we show that a lower share of long-term U.S. bonds in the ROW portfolio would reduce the international spillover effects of $\mathrm{QE}$ on the ROW term premium and aggregate demand, while not altering its domestic effects in the United States significantly.

\footnotetext{
${ }^{25}$ We thus implicitly assume that policy-makers in the United States face a given output gap, and have both conventional and unconventional monetary policy tools at their disposal in order to close this gap.

${ }^{26}$ In fact, the term premium increases very slightly, due to the decline in the short-term domestic bond holdings of ROW agents. This occurs since the government supplies fewer short-term bonds given the decline in its overall interest burden, while keeping long-term bonds in fixed supply in the absence of QE.

${ }^{27}$ The result on the U.S. term premium would be similar even if we introduce money into our model and implement conventional policy changes using open-market operations, as long as short-term bonds and money are treated as perfect substitutes by agents (which would be the case at the zero lower bound). In particular, open-market purchases would change the relative amounts of currency and short-term bonds held by agents, but would not alter the relative composition of long-term assets to short-term assets (which in this case would include currency as well).
} 


\section{$5 \quad$ Sensitivity Analysis}

\subsection{The share of long-term bonds in the foreign asset portfolio}

Figure 7 shows the domestic and the international spillover effects of QE with different values for the share of U.S. long-term bonds in the ROW portfolio. If the ROW holds only long-term bonds in their foreign portfolios, the effects of QE on both the U.S. and ROW output levels increase relative to the baseline case. In particular, the same QE shock in percentage terms now results in a higher relative supply change in U.S. long-term bonds outstanding, therefore lowering the U.S. term premium and long-term rates further. More importantly, there is less overall substitution toward short-term U.S. bonds following QE, when ROW agents do not hold any U.S. short-term bonds. Since ROW agents do not absorb any of the increase in short-term U.S. bonds, a change in the relative supply of short-term bonds now has a larger impact on the U.S. term premium; in particular, the fall in the U.S. long-term yields is now twice as large as it is in the baseline scenario.

In terms of international spillovers, when the ROW holds only long-term U.S. bonds in their foreign asset portfolios, the ROW currency appreciates by $4.5 \%$, ROW GDP increases by $0.35 \%$ and ROW long-term rates fall by $6.5 \mathrm{bps}$, compared to $1.6 \%, 0.2 \%$ and $4 \mathrm{bps}$, respectively, under the baseline case. Note that, unlike the baseline case, the fall in long-term yields is now driven by lower current and future expected short-term rates in the ROW. The long-term interest rate differential is now larger, and therefore leads to a bigger appreciation of the ROW currency, which in turn generates lower inflation and policy rates in the ROW. Thus, the larger share of U.S. long-term bonds in the ROW portfolio amplifies the effects from the long-term UIP condition. On the other hand, the ROW term premium increases in this scenario, rather than fall. This is because, unlike in the baseline scenario, U.S. QE does not increase ROW residents' relative holdings of their domestic long-term bonds. QE in the United States makes ROW agents switch their demand toward bonds other than U.S. long-term bonds. However, the ROW government bond supply does not increase (since there is no QE in the ROW), and the ROW does not hold any short-term U.S. bonds in this case, meaning that ROW holdings of U.S. long-term bonds do not change significantly in equilibrium. The share of long-term assets in the overall portfolio slightly increases in this scenario, since lower interest payments decrease the issuance of ROW short-term government bonds through the government budget constraint. As a result, relative holdings of domestic long-term bonds decrease, increasing the ROW term premium slightly. This, however, does not offset the effect of lower policy rates on long-term yields.

Conversely, when the ROW does not hold any long-term U.S. government bonds, QE does not significantly transmit cross-border, but still affects U.S. economic activity, albeit slightly less than it does under the baseline case. Although very small, international spillovers are not zero in this case, since the rise in U.S. GDP increases imports from the ROW, generating inflationary pressures without a large appreciation. In this 
case, QE spillovers mainly work through the trade channel rather than the financial channel ${ }^{28}$ The fact that the trade channel by itself cannot significantly increase ROW GDP confirms the notion that the financial channel is crucial to generate large international spillovers from QE.

\subsection{Elasticity of substitution parameters in the portfolio specification}

We next analyze the sensitivity of results to elasticity parameters in our portfolio specification. We start with the elasticity of substitution between short- and long-term assets, $\lambda_{a}$. Figure 8 shows the impulse responses from a QE shock in the United States for different values of $\lambda_{a}$; namely, when $\lambda_{a}=0.5,2$, and 5029 The figure suggests that spillovers increase when short- and long-term bonds are less substitutable with each other. A lower degree of substitution amplifies the effects of a change in the relative supply of bonds, resulting in a greater fall in long-term rates, which in turn stimulates the U.S. economy further. ROW economic activity increases more as well through the financial channel, with the ROW term premium and long-term yields declining more than they do in the baseline case. Conversely, a value as large as 50 for this elasticity parameter leads to insignificantly small spillovers, since short- and long-term bonds are almost perfectly substitutable.

International spillovers increase with a higher elasticity of substitution between domestic and foreign assets in the ROW's long-term subportfolio, $\lambda_{L}$ (see Figure 9). If ROW residents more easily substitute U.S. bonds with ROW bonds, their relative demand for long-term ROW bonds increases more after a negative shock to the supply of U.S. bonds, thereby lowering long-term yields further, and stimulating aggregate demand more, in the ROW. Higher substitution between these bonds also increases the appreciation rate of the ROW currency. On the contrary, when domestic and foreign bonds are less substitutable, ROW agents do not increase their relative demand for domestic long-term bonds as much as they do in the baseline scenario. This results in a smaller decline (or even an increase) in the ROW term premium relative to the baseline scenario.

In the case of a sufficiently low substitution between domestic and foreign long-term bonds (the green dotted line in Figure 9), the ROW term premium increases, rather than falls, after a QE shock in the United States. This is a result of two offsetting effects on the relative demand for ROW long-term bonds (see equation (16) and Figure 3). Following a QE shock in the United States, on the one hand, ROW households increase their relative demand for long-term domestic bonds as the yields on long-term U.S. bonds decline (a downward shift in the right panel of Figure 3). On the other hand, lower substitutability, or equivalently higher complementarity, between domestic and foreign bonds in the long-term subportfolio pushes the ROW to decrease its relative demand for long-term domestic bonds, while U.S. long-term bond holdings fall to keep the ratio of ROW-to-U.S. assets in the ROW long-term subportfolio closer to its steady-state value (an upward

\footnotetext{
${ }^{28}$ Note that the ROW trade balance now improves, compared to the deterioration in the baseline case. Also, ROW consumption and investment do not change on impact.

${ }^{29}$ Note that we change this parameter for both regions in this exercise.
} 
shift in the right panel of Figure 3). Under sufficiently high complementarity between domestic and foreign assets, the latter effect dominates the former, and leads to a net decrease in the relative demand for long-term domestic bonds, and therefore to an increase in the ROW term premium. Increases in the term premium and long-term yields dampen the stimulative effect on aggregate demand. However, note that the ROW output still increases in this scenario despite the increase in domestic long-term rates. Lower U.S. long-term bond holdings lead to an increase in the share of domestic bonds in the ROW's long-term subportfolio. This lowers the marginal benefit of holding an additional long-term domestic bond, especially under low degrees of substitution between domestic and foreign long-term bonds. The domestic effects of QE in the United States increase in this case, albeit only slightly, when the ROW substitutes U.S. long-term bonds less with their domestic bonds. This is because a low elasticity of substitution between ROW and U.S. long-term bonds also lowers the overall substitutability of short- and long-term U.S. bonds in the world, making a supply shock in the U.S. long-term bond market more effective in altering the U.S. term premium.

Spillover results are somewhat similar when we change the elasticity of substitution between home and foreign bonds in the ROW's short-term subportfolio, $\lambda_{S}$ (see Figure 10). A higher elasticity of substitution between ROW and U.S. bonds in the short-term subportfolio increases spillovers on the ROW GDP. However, now, GDP in the ROW is more sensitive to changes in this elasticity parameter than the one in the long-term subportfolio. This is mainly because the ROW currency appreciates less when ROW and U.S. short-term bonds are more substitutable, unlike the case with substitution between the long-term bonds. Because shortterm interest rates cannot change in the United States, the ROW currency does not appreciate significantly when short-term ROW and U.S. bonds are almost perfectly substitutable (i.e., $\lambda_{S}=50$ ). As a result, the ROW trade balance improves, and contributes more to the increase in real GDP, relative to an increase in the elasticity parameter in the long-term subportfolio. Furthermore, lower appreciation lifts the disinflationary pressures of appreciation present in the baseline case, and leads to lower short-term real rates, stimulating domestic demand as well.

\section{Conclusion}

In this paper, we study the international spillovers of QE policies in a two-country, open-economy model with portfolio balance effects. Portfolio balance effects arise from imperfect substitution between short- and long-term bonds in portfolio preferences that we introduce into an otherwise stylized two-country DSGE model with nominal and real rigidities. This imperfect substitution leads to lower long-term yields in the U.S. economy as a response to QE, generating appreciation pressures on the ROW currency as well as lower bond yields. Lower yields, in turn, stimulate the economy in the ROW. We show that appreciation occurs even when the short-term rates are constant in the U.S. economy, because the decision between holding a short-term domestic and foreign bond depends not only on the short-term rate differential, but also on the 
quantity of short-term bonds. The latter falls with QE, making domestic short-term bonds less attractive.

When calibrated to the U.S. and ROW economies, our model suggests that international spillover effects of QE in the United States on ROW economic activity and asset prices are larger than those from conventional policy. This is because portfolio balance effects on the ROW's term premium appear more strongly in the case of unconventional monetary policy, causing a larger drop in ROW long-term yields, relative to a U.S. interest rate cut. Furthermore, the fact that the ROW's foreign portfolio is heavily weighted toward long-term U.S. bonds amplifies the spillover effects of unconventional monetary policy relative to a conventional one. Our results indicate that the spillover effects of QE would increase if ROW agents hold more U.S. long-term bonds in their portfolios at the steady state, if they substitute short-term bonds for long-term ones in lower degrees, or if they substitute long-term home bonds for long-term foreign bonds in higher degrees.

\section{References}

[1] Adolfson, M., S. Laséen, J. Lindé, and M. Villani (2008). "Evaluating an estimated new Keynesian small open economy model," Journal of Economic Dynamics and Control, 32, 2690-2721.

[2] Andres, J., J. D. Lopez-Salido, and E. Nelson (2004). "Tobin's imperfect asset substitution in optimizing general equilibrium," Journal of Money, Credit and Banking, 36, 665-690.

[3] Bauer, M. D., and C. J. Neely (2014). "International channels of the Fed's unconventional monetary policy," Journal of International Money and Finance, 44, 24-46.

[4] Baumeister, C., and L. Benati (2013). "Unconventional Monetary Policy and the Great Recession: Estimating the Macroeconomic Effects of a Spread Compression at the Zero Lower Bound," International Journal of Central Banking, 9, 165-212.

[5] Benes, J., A. Berg, R. A. Portillo, and D. Vavra (2013a). "Modeling sterilized interventions and balance sheet effects of monetary policy in a New-Keynesian framework," IMF Working Paper No. 13/11.

[6] Benes, J., M. K. Johnston, and S. Plotnikov (2013b). IRIS Toolbox Release 20130208 (Macroeconomic modeling toolbox), software available at http://www.iris-toolbox.com.

[7] Bernanke, B. S. (2012). "Monetary Policy Since the Onset of the Crisis," Speech at the Federal Reserve Bank of Kansas City Economic Symposium, Jackson Hole, Wyoming, 31 August.

[8] Blanchard, O., F. Giavazzi, and F. Sa (2005). "The US current account and the dollar," NBER Working Paper No. 11137. 
[9] Blundell, R., and T. MaCurdy (1999). "Labor supply: A review of alternative approaches," Handbook of Labor Economics, 3, 1559-1695.

[10] Chen, H., V. Curdia, and A. Ferrero (2012a). "The Macroeconomic Effects of Large-Scale Asset Purchase Programmes," Economic Journal, 122, F289-F315.

[11] Chen, Q., A. Filardo, D. He, and F. Zhu (2012b). "International spillovers of central bank balance sheet policies", in Are central bank balance sheets in Asia too large?, BIS Papers No. 66, 230-74.

[12] Coeurdacier, N., and H. Rey (2013). "Home Bias in Open Economy Financial Macroeconomics." Journal of Economic Literature, 51, 63-115.

[13] Curdia, V., and M. Woodford (2011). "The Central Bank Balance Sheet as an Instrument of Monetary Policy," Journal of Monetary Economics, 58, 54-79.

[14] Dahlhaus, T., K. Hess, and A. Reza (2014). "International Transmission Channels of U.S. Quantitative Easing: Evidence from Canada," Bank of Canada Working Paper No. 2014-43.

[15] D'Amico, S., W. English, D. López-Salido, and E. Nelson (2012). "The Federal Reserve's Large-scale Asset Purchase Programmes: Rationale and Effects," The Economic Journal, 122, F415-F446.

[16] Doh, T. (2010). "The efficacy of large-scale asset purchases at the zero lower bound," Federal Reserve Bank of Kansas City Economic Review, 95, 5-34.

[17] Dorich, J., R. Mendes, and Y. Zhang (2012). "Quantitative Easing at the Zero Lower Bound," mimeo, Bank of Canada.

[18] Fratzscher, M., M. Lo Duca, and R. Straub (2013). "On the international spillovers of US quantitative easing," DIW Berlin Discussion Paper No. 1304.

[19] Gagnon, J., M. Raskin, J. Remache, and B. Sack (2011). "The financial market effects of the Federal Reserve's large-scale asset purchases," International Journal of Central Banking, 7, 3-43.

[20] Gertler, M., S. Gilchrist, and F. M. Natalucci (2007). "External Constraints on Monetary Policy and the Financial Accelerator," Journal of Money, Credit and Banking, 39, 295-330.

[21] Greenwood, R., and D. Vayanos (2010). "Price pressure in the government bond market," American Economic Review, 100, 585-590.

[22] Greenwood, R., and D. Vayanos (2014). "Bond supply and excess bond returns," Review of Financial Studies, 27, 663-713. 
[23] Hamilton, J. D., and J. C. Wu (2012). "The effectiveness of alternative monetary policy tools in a zero lower bound environment," Journal of Money, Credit and Banking, 44, 3-46.

[24] Harrison, R. (2011). "Asset purchase policies and portfolio balance effects: a DSGE analysis," in Chadha, J. and Holly, S. (eds.), Interest rates, prices and liquidity, Cambridge University Press, ch. 5.

[25] Harrison, R. (2012). "Asset purchase policy at the effective lower bound for interest rates," Bank of England Working Paper No. 444.

[26] Hau, H., and H. Rey (2004). "Can portfolio rebalancing explain the dynamics of equity returns, equity flows, and exchange rates?," NBER Working Paper No. 10476.

[27] Krishnamurthy, A., and A. Vissing-Jorgensen (2011). "The effects of quantitative easing on interest rates: channels and implications for policy," NBER Working Paper No. 17555.

[28] Kumhof, M. (2010). "On the theory of sterilized foreign exchange intervention," Journal of Economic Dynamics and Control, 34, 1403-1420.

[29] Lewis, K. K. (1995). "Puzzles in international financial markets," Handbook of International Economics, $3,1913-1971$.

[30] Lim, J. J., S. Mohapatra and M. Stocker (2014). "Tinker, Taper, QE, Bye? The Effect of Quantitative Easing on Financial Flows to Developing Countries," The World Bank Policy Research Working Paper No. 6820 .

[31] Meaning, J., and F. Zhu (2011). "The Impact of Recent Central Bank Asset Purchase Programmes." BIS Quarterly Review, December, 73-83.

[32] Neely, C. J. (2013). "Unconventional monetary policy had large international effects," Working Paper Series No. 2010-018E, Federal Reserve Bank of St. Louis.

[33] Rotemberg, J. J. (1982). "Monopolistic Price Adjustment and Aggregate Output," Review of Economic Studies, 49, 517-31.

[34] Smets, F., and R. Wouters (2007). "Shocks and Frictions in US Business Cycles: A Bayesian DSGE Approach," American Economic Review, 97, 586-606.

[35] Tobin, J. (1969). "A general equilibrium approach to monetary theory," Journal of Money, Credit and Banking, 1, 15-29.

[36] Vayanos, D., and J. L. Vila (2009). "A preferred-habitat model of the term structure of interest rates," NBER Working Paper No. 15487. 
[37] Woodford, M. (2001). "Fiscal requirements for price stability," NBER Working Paper No. 8072.

[38] Wright, J. H. (2012). "What does Monetary Policy do to Long-term Interest Rates at the Zero Lower Bound?" The Economic Journal, 122(564), F447-F466. 
Table 1: Parameter Values

\begin{tabular}{|c|c|c|c|c|c|}
\hline Parameter & Value & Source & Parameter & Value & Source \\
\hline Portfolio & & & Preferences & & \\
\hline Home share (short), $\gamma_{S}, \gamma_{S}^{*}$ & $0.85,1$ & calibrated & Discount factor, $\beta$ & 0.98 & calibrated \\
\hline Home share (long), $\gamma_{L}, \gamma_{L}^{*}$ & $0.62,1$ & calibrated & Cons. habit, $\zeta$ & 0.7 & literature \\
\hline Short share, $\gamma_{a}, \gamma_{a}^{*}$ & $0.59,0.66$ & calibrated & Labor elasticity, $\vartheta$ & 1 & literature \\
\hline Elasticity, $\lambda_{a}$ & 2 & calibrated & Portfolio coefficient, $\xi_{a}, \xi_{a}^{*}$ & $0.05,0.04$ & literature \\
\hline Elasticity, $\lambda_{S}, \lambda_{L}$ & 3.4 & calibrated & Labor coefficient, $\xi_{n}, \xi_{n}^{*}$ & $22.46,23.10$ & calibrated \\
\hline Coupon, $\kappa$ & 0.98 & calibrated & & & \\
\hline Technology & & & Taylor rule and Gov't & & \\
\hline Home biasness, $\gamma_{c}, \gamma_{i}$ & 0.90 & calibrated & R persistence, $\rho$ & 0.80 & literature \\
\hline Elas. $\mathrm{H}$ and $\mathrm{F}$ cons., $\lambda_{c}$ & 1 & literature & Inflation sensitivity, $r_{\pi}$ & 1.75 & literature \\
\hline Elas. $\mathrm{H}$ and $\mathrm{F}$ inv., $\lambda_{i}$ & 0.25 & literature & Output gap sensitivity, $r_{y}$ & 0.05 & literature \\
\hline Markup, $\theta_{w}, \theta_{h}, \theta_{f}$ & 1.5 & literature & Output growth sensitivity, $r_{\Delta y}$ & 0.05 & literature \\
\hline Indexation, $\varsigma_{w}, \varsigma_{h}, \varsigma_{f}$ & 0.50 & literature & Tax coefficient, $\Xi, \Xi^{*}$ & $0.17,0.19$ & calibrated \\
\hline Price adj. cost, $\kappa_{p h}, \kappa_{p f}$ & 35 & calibrated & Elasticities in tax policy, $\tau_{y}, \tau_{b}$ & 0.5 & set \\
\hline Wage adj. cost, $\kappa_{w}$ & 80 & calibrated & QE shock persistency, $\rho_{b}$ & 0.95 & set \\
\hline Capital exponent, $\alpha$ & 0.34 & calibrated & & & \\
\hline Depreciation rate, $\delta$ & 0.02 & calibrated & & & \\
\hline Inv. adj. cost, $\varphi$ & 2 & calibrated & & & \\
\hline Utilization elasticity, $\varpi$ & 0.12 & literature & & & \\
\hline Utilization adj. cost, $\kappa_{u}$ & 0.03 & calibrated & & & \\
\hline
\end{tabular}


Figure 1: Nominal Exchange Rates and Government Bond Yields over 2010-2014

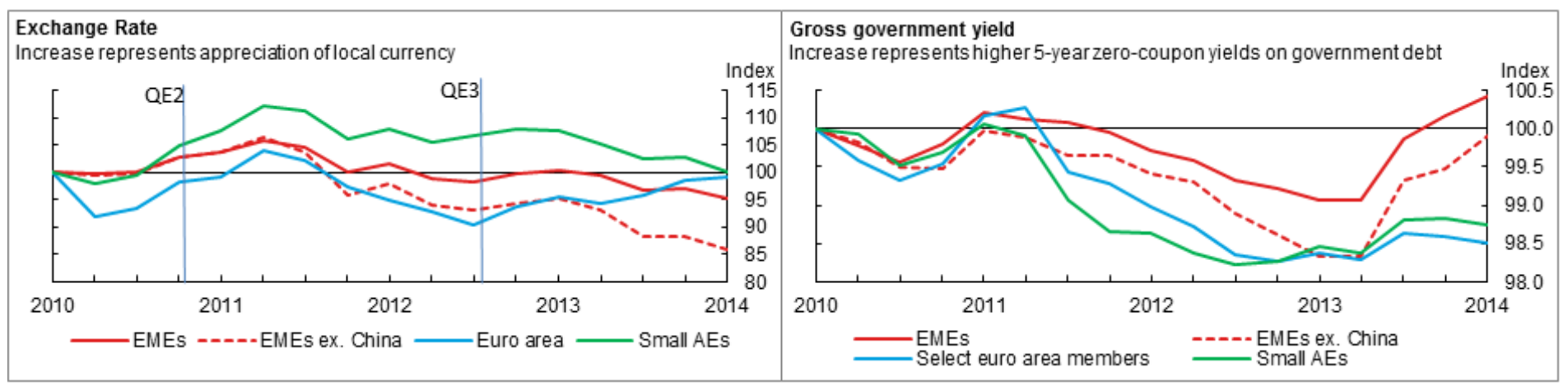

Notes: EMEs include Brazil, Chile, China, Colombia, Hungary, India, Indonesia, Israel, Korea, Malaysia, Mexico, Peru, Philippines, Poland, Russia, South Africa, Taiwan, Thailand, Turkey. Small advanced economies (AEs) include Australia, Canada, Denmark, Norway, Sweden, Switzerland. Select euro members are Austria, Finland, France, Germany, Netherlands.

Figure 2: U.S. Residents' and ROW Holdings of U.S. Short-term and Long-term Government Bonds

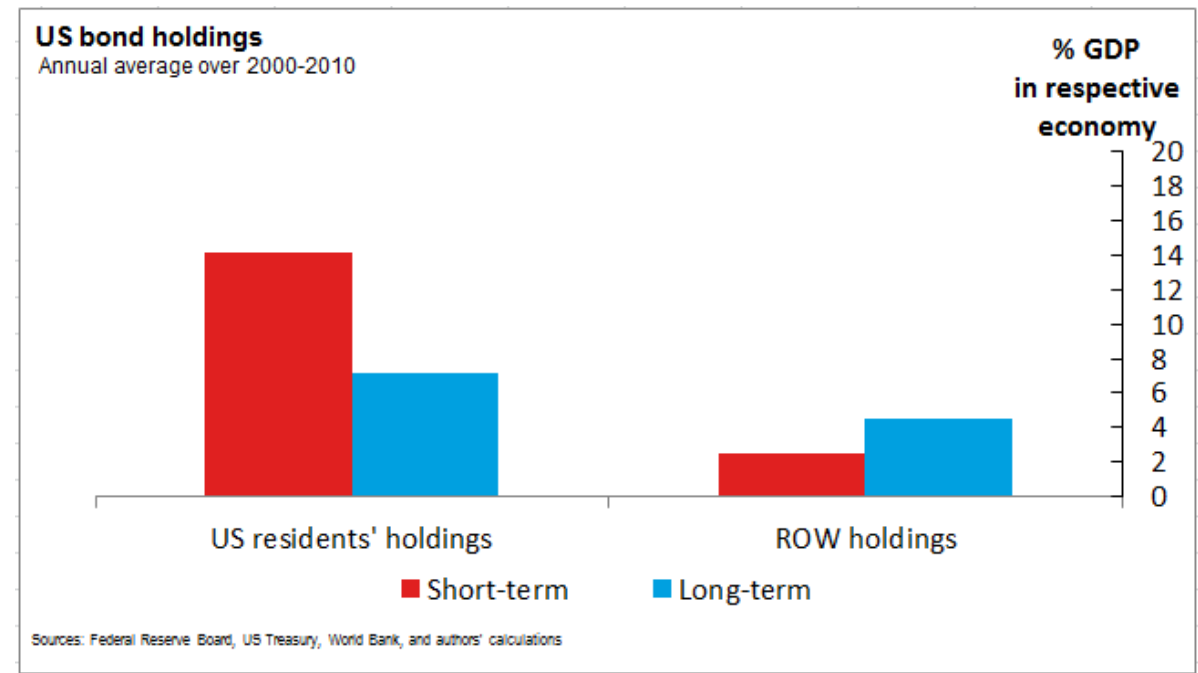

Notes: Short-term bonds include U.S. Treasury securities with a maturity of less than one year, financial institutions' reserves at the Federal Reserve System, vault cash and currency outside banks. Long-term bonds consist of U.S. Treasury bills with a maturity of more than one year. 
Figure 3: Term Premium in the United States and the Rest of the World

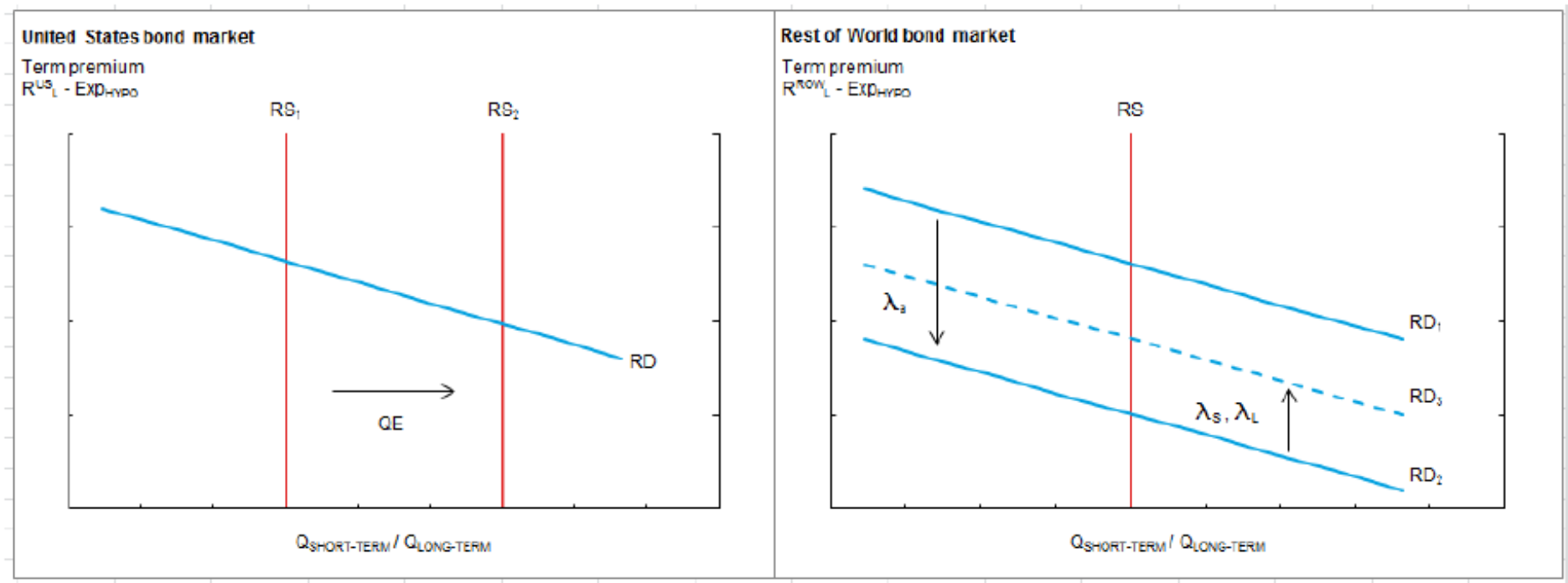

Notes: The vertical and horizontal axes represent the term premium and the quantity of short-term bonds relative to long-term bonds in the bond markets of each region. "RD" and "RS" denote relative demand and relative supply, respectively. $\lambda$ 's denote the elasticity of substitution parameters in the portfolio specification as defined in the text.

Figure 4: U.S. Responses to a QE shock in the United States
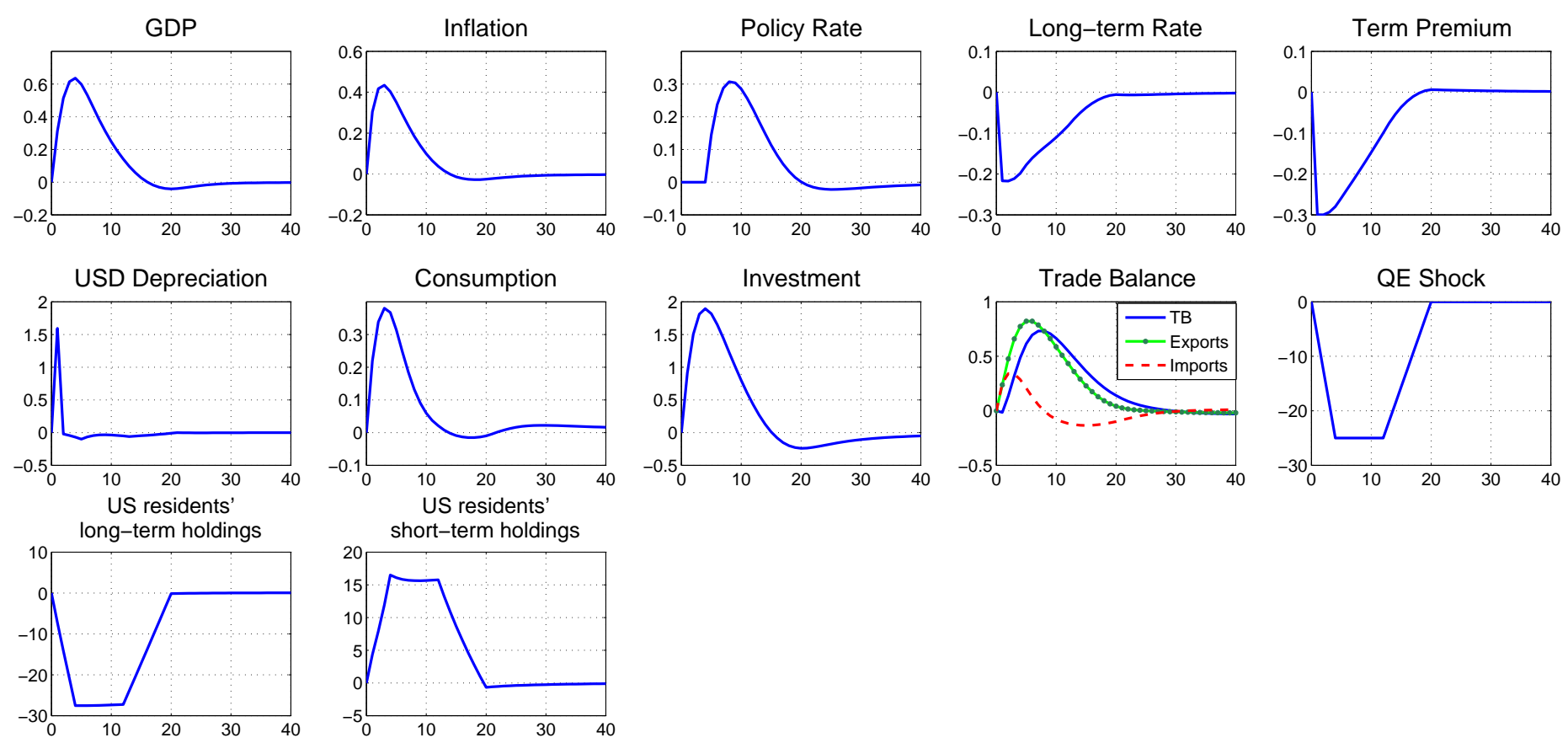
Figure 5: ROW Responses to a QE Shock in the United States
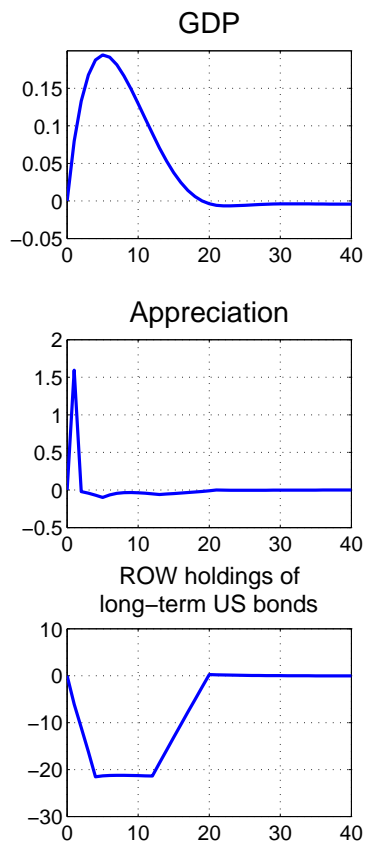
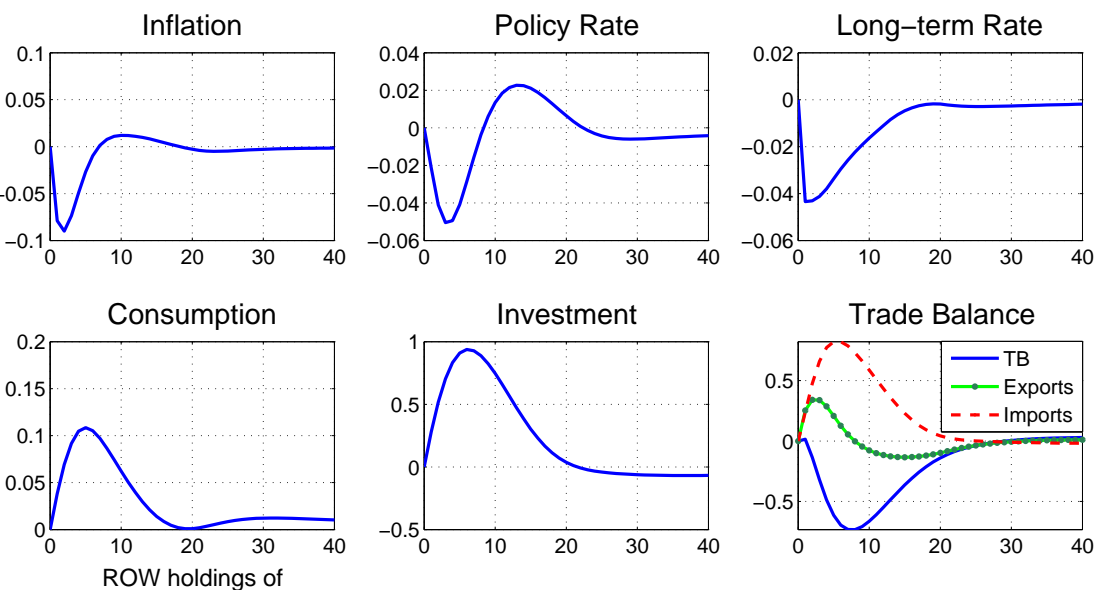

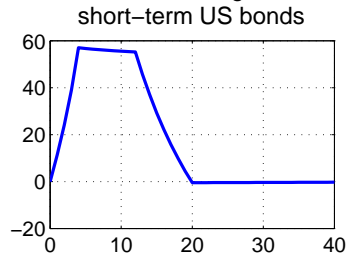

Figure 6: Effects of Conventional versus Unconventional Monetary Policy
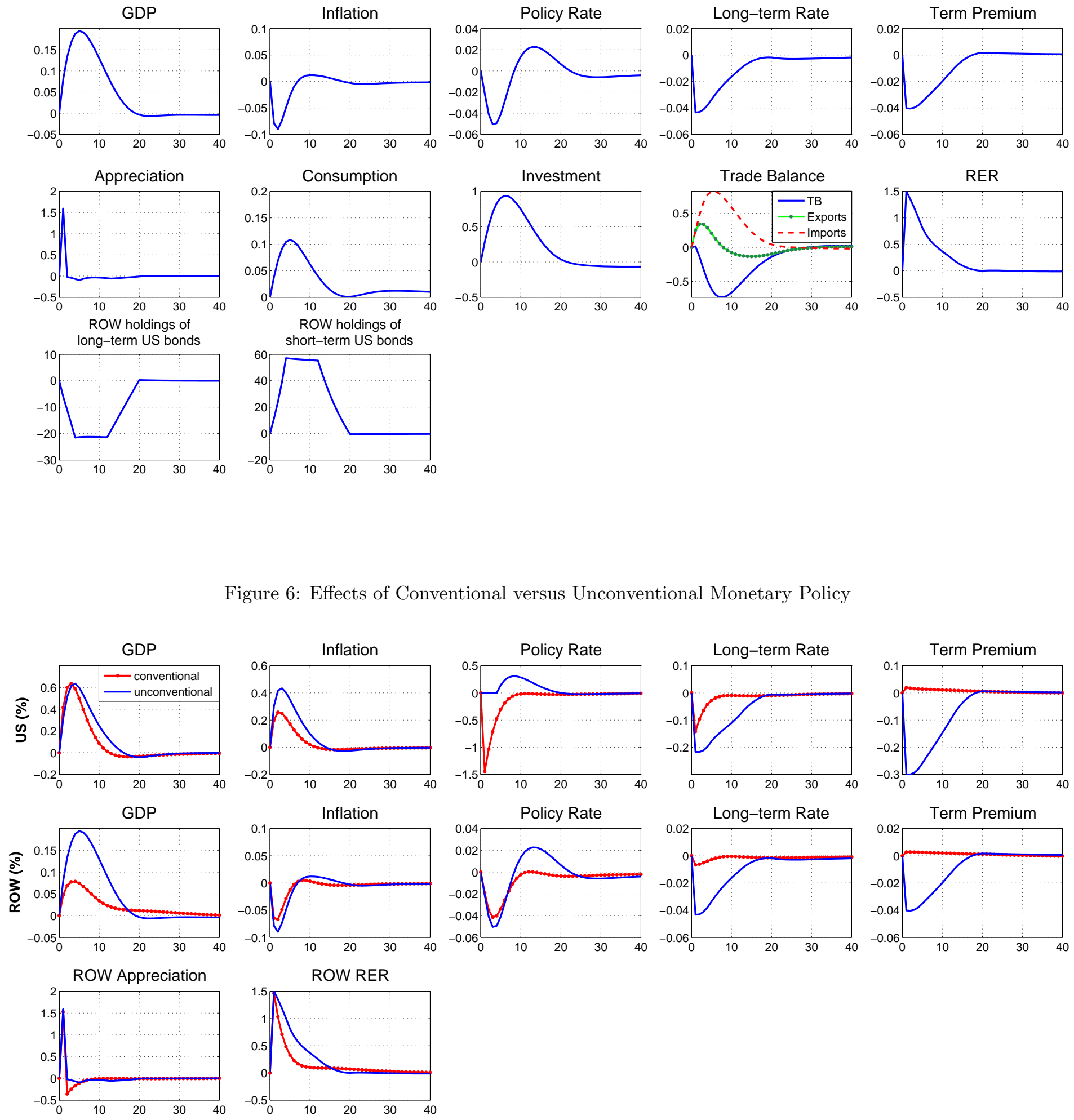
Figure 7: Sensitivity Analysis with Different Maturity Compositions of U.S. Bonds in the ROW Portfolio
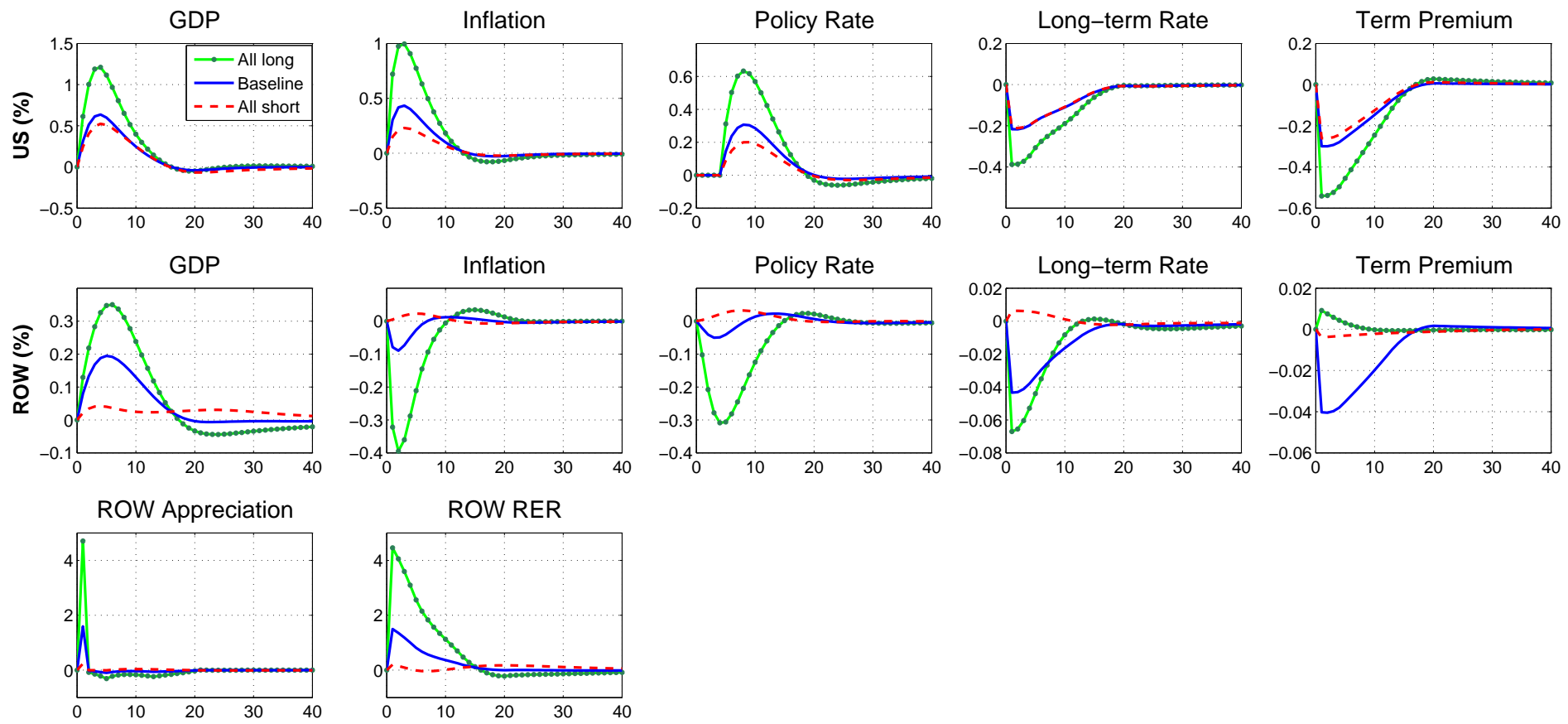

Figure 8: Sensitivity Analysis with Different Elasticity of Substitution between Short-term and Long-term Portfolios
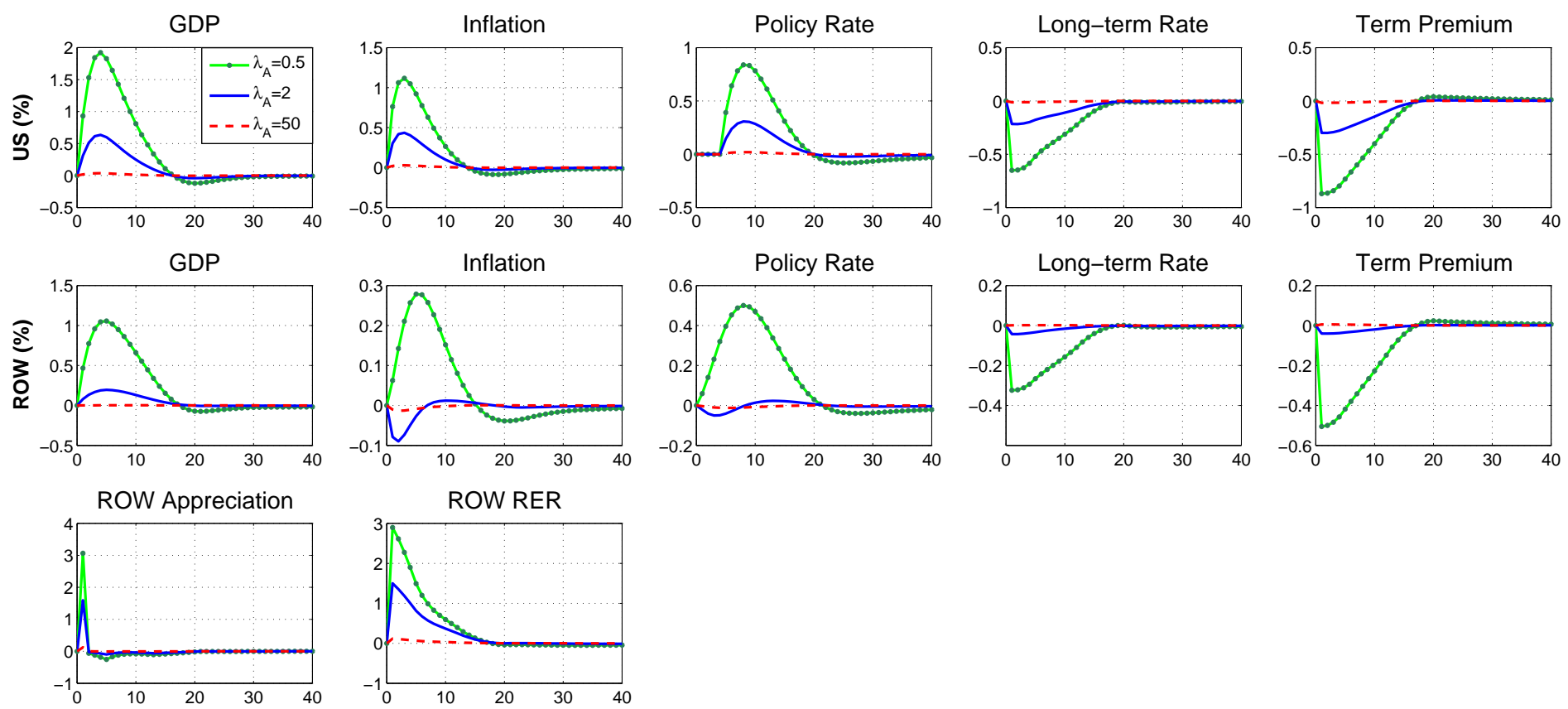
Figure 9: Sensitivity Analysis with Different Elasticity of Substitution between Home and Foreign Bonds in ROW's Long-term Portfolio
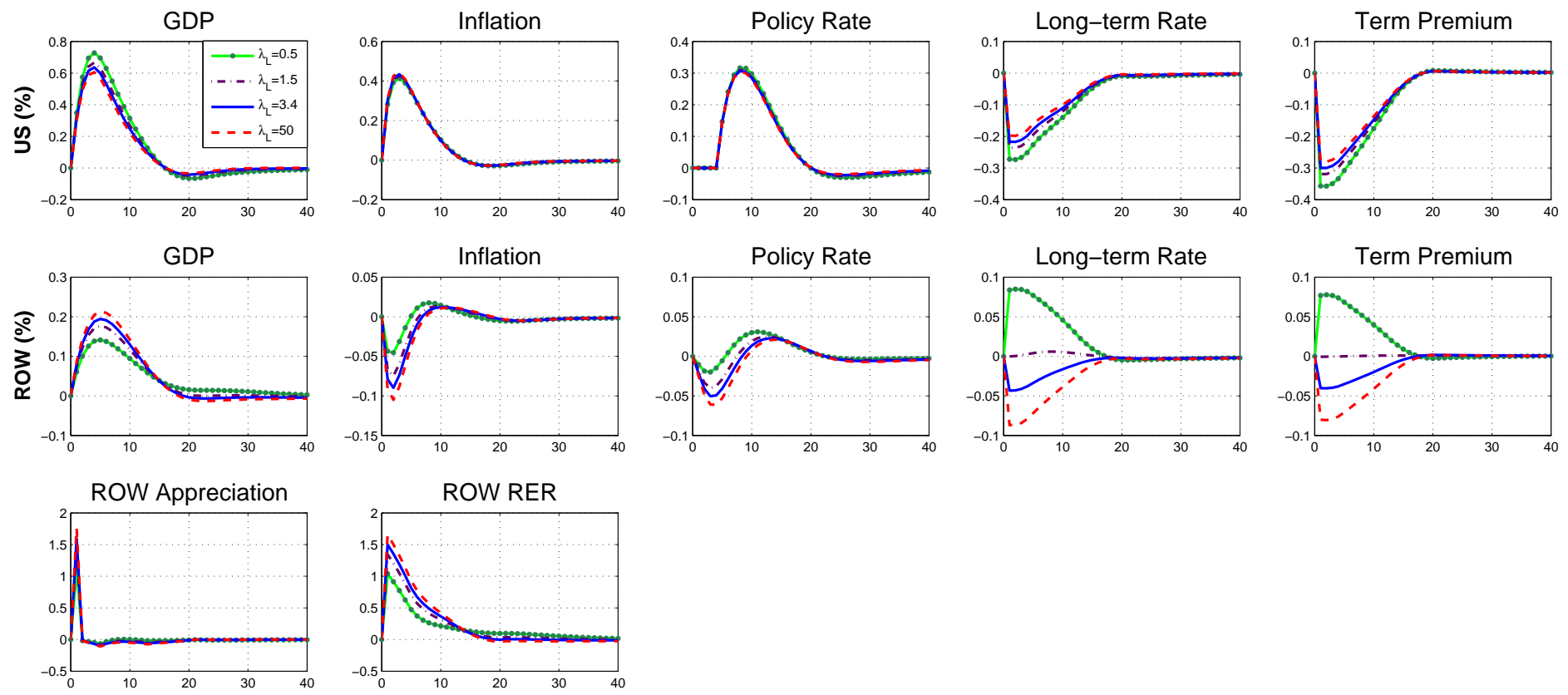

Figure 10: Sensitivity Analysis with Different Elasticity of Substitution between Home and Foreign Bonds in ROW's Short-term Portfolio
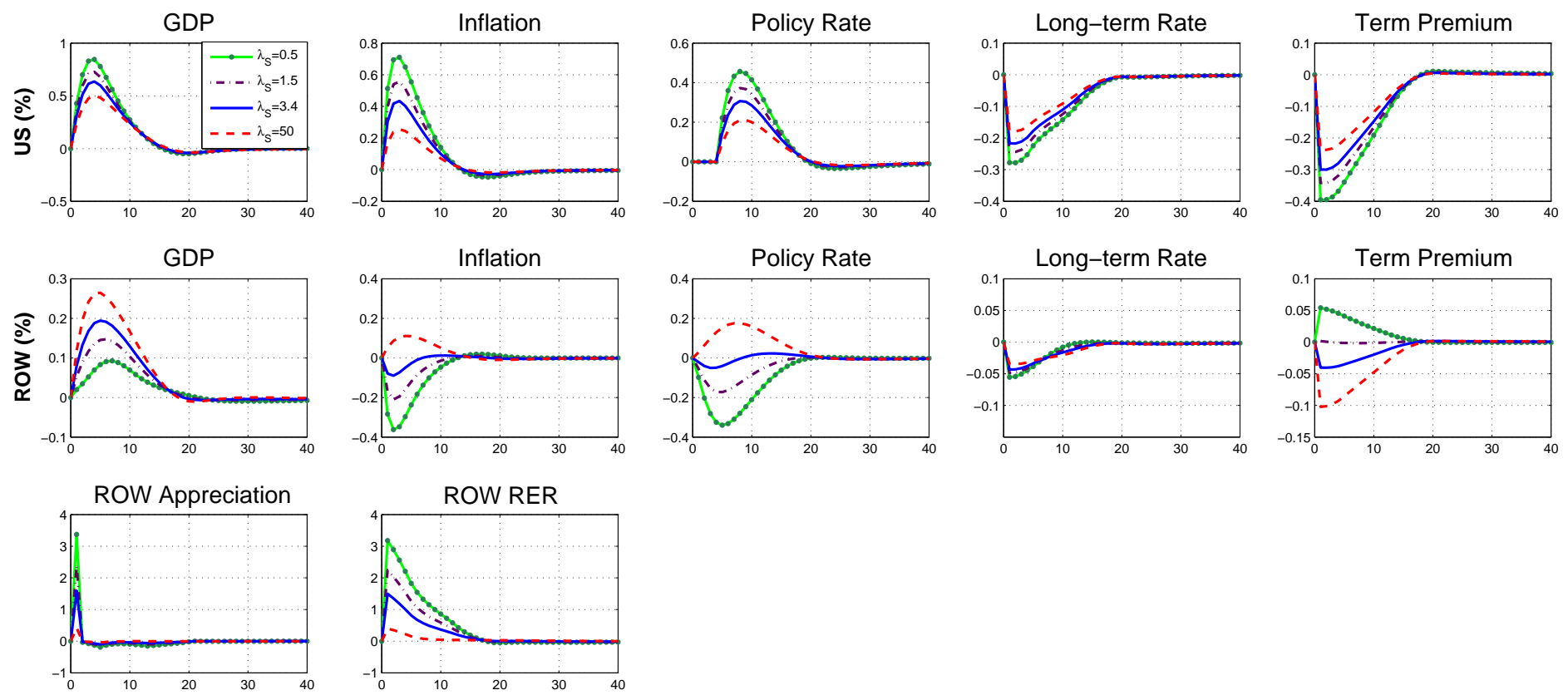